\title{
AN ASSESSMENT OF EXPENDITURES BY CAMP HENRY PATRONS IN NEWAYGO COUNTY
}

\author{
A Thesis \\ Presented to \\ the Faculty of California Polytechnic State University, \\ San Luis Obispo
}

\author{
In Partial Fulfillment \\ of the Requirements for the Degree \\ Master of Science in Agriculture, with Specialization in: \\ Recreation, Parks, \& Tourism Management
}

by

Amy Diane Fitzpatrick

February 2012 
(C) 2012

Amy Diane Fitzpatrick ALL RIGHTS RESERVED 


\section{COMMITTEE MEMBERSHIP}

TITLE:

AUTHOR:

DATE SUBMITTED:

COMMITTEE CHAIR:

COMMITTEE MEMBER:

COMMITTEE MEMBER:
An Assessment of Expenditures by Camp Henry Patrons in Newaygo County

Amy Diane Fitzpatrick

February 2012
Dr. Bill Hendricks, Professor

Dr. Kris Jankovitz, Professor 


\begin{abstract}
An Assessment of Expenditures by Camp Henry Patrons in Newaygo County
\end{abstract}

Amy Diane Fitzpatrick

This thesis evaluates expenditures made by Camp Henry patrons during the 2005 summer camp season while traveling to and from the residential camp located in Newaygo County, Michigan. A purposive random cluster sample was collected via selfadministered questionnaire on the arrival days of weeks 3, 7, and 8 of the 8 week summer camp season. The data revealed expenditures in each of the categories on the instrument; lodging expenses, food and beverages, private auto expenses, retail shopping, recreation activities, and "other". Expenditures for the 55 participants and the individuals traveling with them totaled $\$ 4,558$. The category with the greatest reported expenditures was food and beverage, totaling $\$ 1,645$ and the category with the least reported expenditures was lodging, totaling $\$ 170$.

First summer camper group expenditures and returning camper group expenditures were evaluated to determine if a relationship exists between inexperienced and experienced campers, a one-factor ANOVA was run with the logarithm of total expenditures and, with a $P$ value of 0.077 , no statistically significant relationship is found. A one-factor ANOVA was utilized to evaluate the relationship between participants residing within 35 miles of the residential camp facility and those living further away. With a P value of 0.101 , it is determined that hometown does not have an effect on patron expenditures. A regression analysis of the logarithm of total expenditures and income ranges was performed to determine if an individual's annual income has an effect on expenditures; with a P value of 0.626 no relationship was found. Lastly, a regression analysis of the logarithm of total expenditures and participant age was run to determine if a relationship between a participant's age and the amount spent exists. With a $\mathrm{P}$ value of 0.574 , no statistically significant relationship exists.

Limitations of the study include a small sample size, the inability of participants to accurately predict return trip expenditures, and the close proximity of participant residences to the camp facility.

Although no statistically significant relationships were found, the expenditure information can be used to develop partnerships between local businesses and the residential summer camp. The possibility of exploring the camp going population and their monetary value to host communities is a worthwhile subject for further scrutiny. The information presented here can be used as a starting point for future studies on expenditures of residential camp patrons.

Keywords: residential camp, summer camp, patron expenditures, Camp Henry 


\section{ACKNOWLEDGEMENTS}

There are many individuals who have supported me along the way to completing this thesis. I would like to acknowledge the three members of my thesis committee, Dr. Jeff Jacobs, Dr. Bill Hendricks, and Dr. Kris Jankovitz, for taking the time to guide and assist me during these past 7 years. Thank you for jumping back into this with me after such a long hiatus. I am grateful for the patience and support provided by Dr. Jeff Jacobs, my committee chair, and am thankful for the summers I was able to spend at Camp Henry. I would also like to acknowledge my parents and brother; Paul, Cheryl, and David Fitzpatrick, for their support during the ups and downs of this experience.

Lastly, I'd like to thank Steven Laurie from the University of Oregon in Eugene, Oregon and Professor Heather Smith from California Polytechnic State University’s statistics department for assisting me with the data analysis. I appreciate your time, thoughts, and remote assistance more than you will ever know. 


\section{CONTENTS}

Page

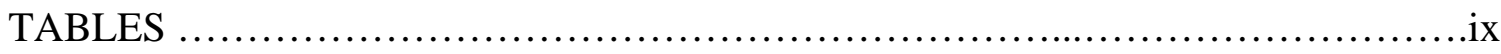

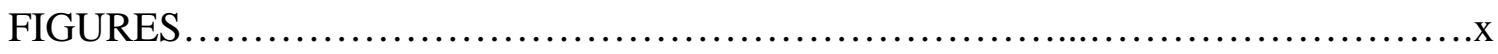

\section{CHAPTER}

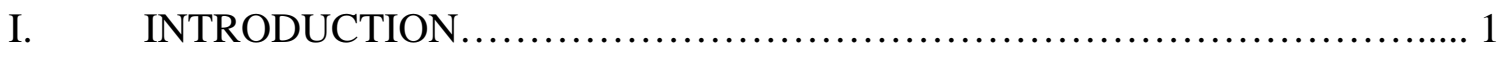

Introduction .......................................................

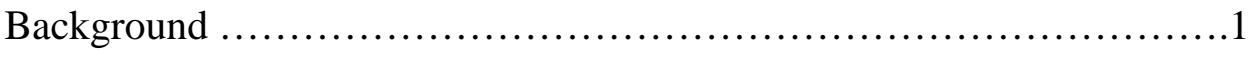

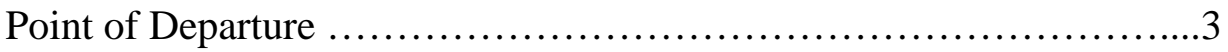

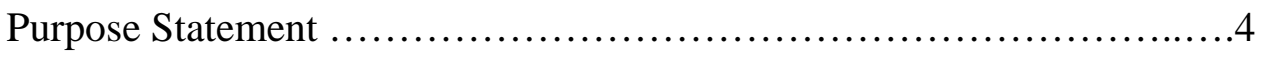

Research Questions .............................................4

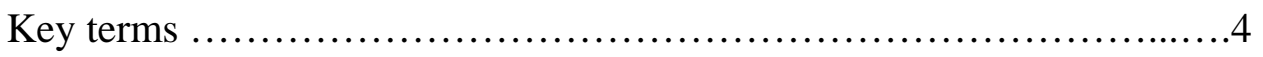

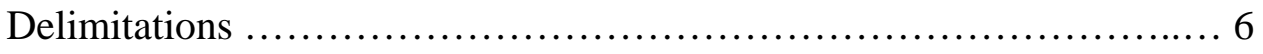

Limitations ............................................................

Basic Assumptions ...............................................

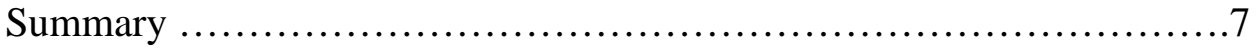

II. REVIEW OF THE LITERATURE ......................................

Regional Economic Impact ...................................... 9

Misapplications of Economic Impact Studies .............................11

Economic Impact of Tourism, Large Scale Events, and Sports Facilities ......................................... 18

Economic Impact of Parks and Campgrounds ........................... 21

Economic Impact in the Camp Setting ............................. 26

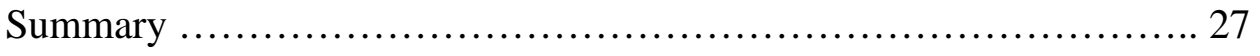


Page

III. METHODOLOGY ..................................................... 29

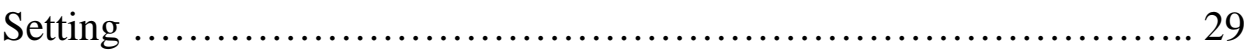

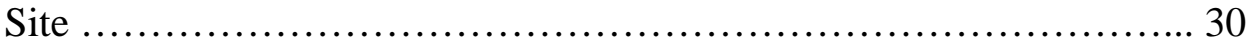

Population of Interest ................................................ 31

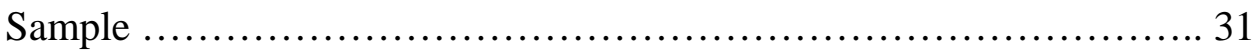

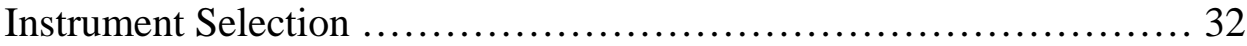

Instrument Design ............................................... 32

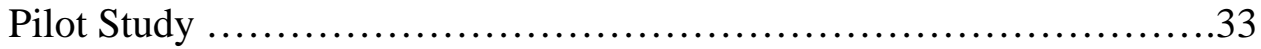

Data Collection Procedure ...............................................34

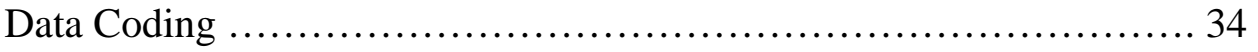

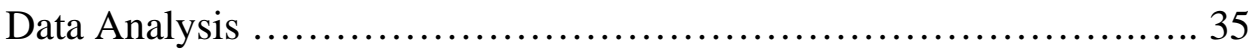

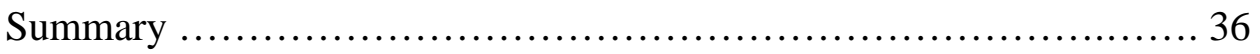

IV. PRESENTATION AND ANALYSIS OF THE DATA .........................37

Participants ...................................................... 37

Analysis of Research Questions ...................................... 40

Presentation of the results ............................................ 44

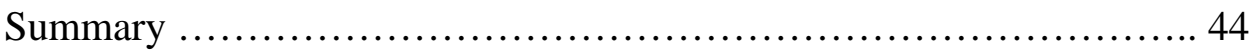

DISCUSSION OF THE FINDINGS AND RECOMMENDATIONS FOR FUTURE RESEARCH ...................... 46

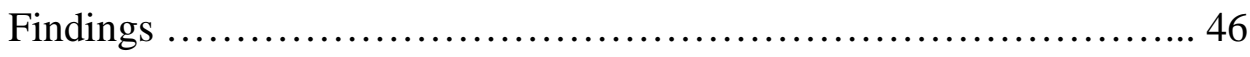

Discussion ......................................................... 47 


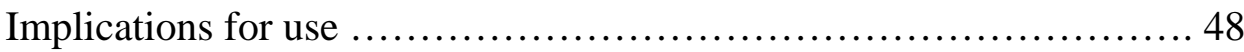

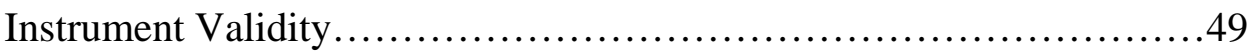

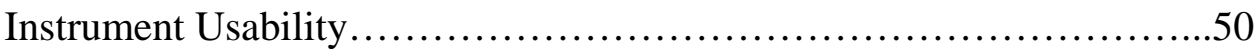

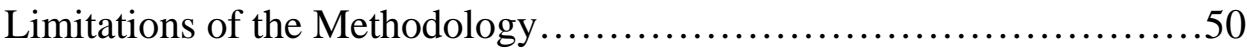

Recommendations for Future Studies..................................53

Recommendations for instrument .............................53

Recommendations for data collection ........................... 54

Recommendations for data analysis .......................... 56

Recommendations for future research ........................ 57

Limitations ..................................................... 58

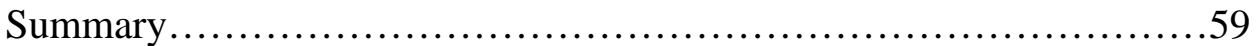

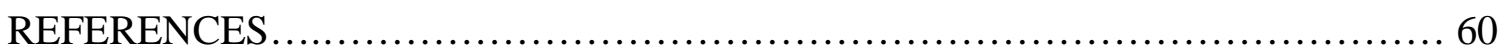

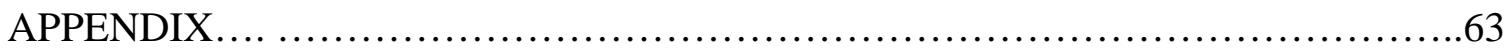

A. Camp Henry Participant Questionnaire ...............................64 


\section{LIST OF TABLES}

Table

Page

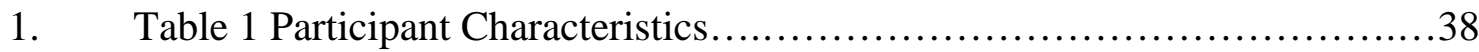

2. Table 2 Participant Income Ranges.................................... 39

3. Table 3 Participant Age, Number, and Average Per Person......................40

4. Table 4 Total and Mean Group Expenditures by Category.....................40

5. Table 5 Participant Zip Code Frequency.................................43

6. Table 6 Participant Zip Code Expenditures................................44

7. Table 7 Total and Mean Group Expenditures by Hometown...................44 


\section{LIST OF FIGURES}

Figure $\quad$ Page

1. Figure 1 Michigan Counties........................................... 28 


\section{CHAPTER 1}

Introduction

\section{Introduction}

Camp Henry, a residential camp and conference center established in 1937, is located in Newaygo County, Michigan. Over the course of its operation, Camp Henry has been a place for youth to engage in safe and enriching summer camp programs, a venue for corporate groups to hold retreats, a location where at-risk youth can participate in character developing challenge programs, and a resource to provide outdoor activities for the general public. Camp Henry contributes to the sentimental and spiritual lives of members of the community, but studies have not determined its financial impact. This study is an attempt to quantify the dollar amount brought into Newaygo County by Camp Henry summer camp patrons.

\section{Background}

There are over 2,400 American Camp Association-Accredited camps throughout the United States, which meet up to 300 safety, health, and programming standards (American Camp Association, 2012). These camps generate economic activity in their host communities that has yet to be adequately measured. "Every local economy is concerned about the regional economic development to create job opportunities, raise incomes, and contribute to the community's social viability and general economic

prosperity" (Loomis \& Walsh, 1997, p. 242). The economic contributions of camps have not been quantified, but state parks are in a similar genre of outdoor recreation and may offer a basis for the economic benefits of camps. Therefore numerous studies involving state parks were reviewed to help inform this study. 
State parks have been found to contribute substantially to their respective host communities. "By understanding the direct and indirect contributions state parks have on local economies, managers are better positioned to argue for increased political and budgetary support" (Donnelly, Vaske, DeRuiter, \& Loomis, 1998, p. 70). Understanding the economic impact of camps may give camp administrators the ability to describe the presence of summer camps as an investment in a local community.

With many camps nationwide experiencing decreases in funding, administrators require information about the financial contributions a camp brings to its host community. "Economic impact studies have been an effective tool in the "battle" to maintain existing tax support” (Kanters, Carter, \& Pearson, 2001, p.49). A relationship between the expenditures of a camp and its patrons in a community showing possible associated economic returns to that community, such as higher levels of employment or increased sales for local vendors, may be established through a study such as this. "A causal linkage should be established between economic effects (e.g., jobs, income) and the program or action being evaluated" (Stynes, 2005, p. 8). In establishing such links, estimates of the financial contributions are more readily accepted.

Knowing the monetary value to a host community of different aspects of the recreation, parks, and tourism industry can help businesses in times of financial instability. Support may be gained from community leaders, regional foundations, community vendors, and the local tourism industry, making funding easier to obtain. "Measures of economic significance are used both internally in resource allocation decisions and externally to demonstrate the contributions of programs to social welfare and regional economic development" (Stynes, 2005, p.1). The findings from this study 
could aid camp administrators in describing how local industry and businesses can benefit financially from the presence of their camp. The findings may also aid camps in gaining partnerships with businesses that would choose to market to the camp community. Every summer, thousands of campers and their parents spend money while preparing for, traveling to, and traveling home from camp. In addition, camps contribute to local economies through the purchase of supplies, materials, food, marketing services, equipment, and utilities as well as by employing local residents. This study investigates one aspect of these valuable economic contributions.

This thesis reports on the economic activity generated within Newaygo County, Michigan by the patrons of Camp Henry while traveling to and from the camp during the summer of 2005. This study is based on responses from parents of campers to a selfadministered questionnaire. This first chapter discusses the point of departure, describes the purpose of the research, lists the research questions, and defines key terms. The chapter concludes by discussing the limitations of the study, listing the basic assumptions made, and summarizing the chapter.

\section{Point of Departure}

Previous studies have considered the economic impacts and economic activity generated by parks and recreation settings. Numerous studies have been published that focus on tourist attractions and large scale events, such as the Olympic Games (Glisson \& Arbes, 1996) and outdoor areas such as state parks (e.g.; Cordell, Bergstrom, \& Watson, 1992; Dean, Getz, Nelson, \& Siegfried, 1978; Donnelly, Vaske, DeRuiter, \& Loomis, 1998). No studies could be found that focused on the economic activity generated by the 
presence of a residential camp on its host community. This study is an attempt at filling this gap in the research.

\section{Purpose Statement}

The purpose of this study is to determine the economic activity generated by the patrons of Camp Henry while traveling to and from the camp in Newaygo County, Michigan during the summer of 2005.

\section{Research Questions}

1) What types of expenditures were made and how much was spent by patrons traveling to and from Camp Henry during the 2005 summer?

2) Do first time campers spend significantly more amounts of money while traveling to and returning from Camp Henry than returning campers?

3) Does hometown, income, or age significantly affect the amount spent by Camp Henry patrons while traveling to and from the residential camp facility?

\section{Key Terms}

Direct effects- "In terms of visitor spending, the changes in economic activity in firms selling directly to visitors, i.e., lodging, restaurant, amusement, transportation, and retail trade sectors" (Stynes, 2005, p. 32).

Economic impact- the amount of revenue activity generated in an area due to particular events such as a festival or tourist trade (Henderson \& Bialeschki, 2002).

Host community- the area housing/surrounding an event or venue that is affected by that event or venue's presence in many ways, including economically. Indirect effects- "Changes in sales, income, or employment within a region in backwardlinked industries supplying goods and services to directly affected businesses. The 
increased sales in linen supply firms resulting from more motel sales are an indirect effect of visitor spending" (Stynes, 2005, p. 32).

Induced effects- "Increased sales within the region from household spending of the income earned through direct and indirect effects. Employees in tourism and supporting industries spend their income on housing, utilities, groceries, and other consumer goods and services, generating sales, income, and employment throughout the region's economy" (Stynes, 2005, p. 32).

Multiplier-"Number used to calculate the size of secondary effects in a region, generally as a ratio of the total change in economic activity in the region relative to the direct change. Multipliers express the degree of interdependence between sectors in a region's economy and are usually derived from I-O (input-output) models. A sector-specific multiplier gives the total change throughout the economy associated with a unit of change in sales in a given region" (Stynes, 2005, p. 32).

Nonresidents- individuals residing outside of the Newaygo County boundaries.

Participants/respondents- interchangeable terms referring to parents who completed the on-site, self-administered questionnaire.

Residents- individuals residing within the borders of Newaygo County.

Secondary effects- "Changes in economic activity from subsequent rounds of spending stimulated by direct sales. There are two types of secondary effects: indirect and induced" (Stynes, 2005, p. 33).

Summer camp season- June 12th to August 14th, 2005

Total effects- The sum of direct, indirect, and induced effects 


\section{Delimitations}

The data collection occurred during weeks three, seven, and eight of the eight week summer camp season of 2005. The dates for data collection were July $3^{\text {rd }}$, July $31^{\text {st }}$, and August $8^{\text {th }}$. Study participants were asked to report expenditures in an informal data collection setting, while in the residential camp check-in line on the first day of camp, where factors such as weather, temperature, noise, and stress can play a role in an individuals decision to participate. Respondents were asked to recall and accurately report the expenditures they had made while traveling to Camp Henry. Respondents were also asked to predict and report their return trip expenditures. Respondents were self selected to participate. The respondents were required to be able to read English at an approximate $5^{\text {th }}$ grade reading level.

\section{Limitations}

This study is limited by the number of respondents willing to participate in, or complete, the survey. It is limited by the number of individuals choosing to pass the clipboard back in line to the next available individual. It is limited by the number of researchers available to assist in data collection. It is limited by the exclusion of data from local businesses and by the exclusion of data from resident camp staff expenditures, as well expenditures of holdovers (campers staying for more than one consecutive week, being cared for and entertained by resident camp staff in Newaygo County). The study used a self-administered questionnaire to measure participant expenditures; no direct observations were made. 


\section{Basic Assumptions}

The researcher assumed that the respondents completed the questionnaire truthfully and to the best of their ability. It was assumed that respondents had the ability to remember and report what expenditures they had made and that they were aware of and reported all expenditures for their group. It was also assumed that the respondents would be able to accurately approximate their return expenditures.

\section{Summary}

This chapter provides an overview of the study. The residential camp and conference facility, Camp Henry, is being studied. The research questions focus on what expenditures are made by patrons of the facility, within the boundaries of Newaygo County, while traveling to and from the site. The differences between first time and returning campers in regards to expenditures and the consideration of the factors of age, income level, and hometown on expenditures are also included in the research questions. Many state parks have been evaluated on the basis of economic activity generated within their host communities. Due to the similarities between park and recreation areas and residential camp settings, numerous research articles focusing on these venues are included to inform this study. Respondents were self selected to participate in the study. Respondents were asked to report expenditures made while traveling to Camp Henry within the limits of Newaygo County and were asked to predict and report return trip expenditures within the county limits, as well. This study has a few limitations, including the willingness of individuals to participate and the number of researchers available to assist with data collection. Basic assumptions included the idea that respondents would complete the questionnaires truthfully and to the best of their ability, respondents would 
be able to recall and report the expenditures for their entire group, and that they would be able to approximate return trip expenditures. 


\section{CHAPTER 2}

Review of the Literature

In many cases, regional economic activity is measured through an economic impact study. Due to many factors that will be discussed in detail in Chapter Five, this study cannot be classified as such based on the criteria defined for economic impact studies. Although this classification cannot be used, it is still valuable to have an understanding of the economic activity and impact of a residential camp. The review of the literature discusses regional economic impact, describes the common misapplications of economic impact studies, reviews economic impact studies conducted on large scale events and festivals, and delves more specifically into economic impact in parks, campgrounds, and related settings. This review provides a foundation for developing an appropriate approach to study the expenditures generated by the patrons of Camp Henry in Newaygo County, Michigan during the summer of 2005.

\section{Regional Economic Impact}

Regional economic impact studies estimate the changes in a region's economic activity resulting from some action (Stynes, 2005). An "action" may include the building of a sports arena or field, holding a festival, building homes near a golf course or open space, harvesting timber, or developing a state park. Each action has the possibility of bringing money to, or generating revenue within, its region. "The most direct impacts of activities on public lands involve nearby businesses, households, and units of government" (Stynes, 2005, p. 2). Any type of attraction that brings individuals to a region (who would otherwise spend their time and money elsewhere) has the potential to benefit businesses, which employ residents, who pay taxes to the government, which may 
subsidize the attraction. The cycle begins again with the government subsidizing the same attraction or with the subsidization of a new attraction. Much of the debate over subsidizing a facility or event revolves around the level of economic return that the taxpayers are likely to receive on their money (Crompton, 2004, p. 42).

Money flows into an area from nonresidents, or visitors, and that money is income that is injected into the local economy. The multiplier effect stimulates further employment and income within the community and the local economic community is maintained (Loomis \& Walsh, 1997). "Economic development is a political priority in most communities because it is viewed as a means of enlarging the tax base" (Crompton \& Lee, 2000, p. 108). This tax base can provide additional revenues that can be used by local governments to improve the community's facilities, infrastructure, and services. It can also be used to reduce the level of taxes paid by residents and is also seen as a way to improve residents' quality of life through jobs and income (Crompton \& Lee, 2000). Community leaders are concerned about regional economic development to raise incomes, create job opportunities, and contribute to a community's social viability and economic prosperity (Loomis \& Walsh, 1997).

Crompton and Lee (2000) state that economic impact studies provide "best guesses" rather than concrete accuracy. Although the impact calculated is not a completely accurate, down-to-the-dollar exact amount, when conducted and interpreted properly, this estimate can be representative of the actual economic activity present in a community. The following section discusses ways economic impact studies have been misapplied and misinterpreted in the past and gives the reader the tools needed to interpret reports of economic impact with a critical eye. 


\section{Misapplications of economic impact studies}

An economic impact study is based on numerous criteria which are often overlooked, misused, or abused by those conducting the study or by those interpreting the results. Many of the misapplications of economic impact studies (Crompton, 1995) are explained below, including the misuse of multipliers, measuring benefits while not considering costs, including local residents, and omitting opportunity costs. Those that did not apply to this study were not described in detail, but are included in the list of the common misapplications at the end of this section.

Increasing pressure on community officials to show the efficacy of their tax dollar allocations often leads to the commission of economic impact analyses. They want to quantify the profit made as a result of subsidization of development projects. Many times this is to convince voters of the worthiness of something such as a sports subsidy, suggesting that the subsidy will inject many millions of dollars into the local economy each year. Often times this is not the case and those conducting the study are neither impartial nor objective and are working for their own benefit (Crompton, 1995). It is possible to have six different groups conduct a study in the same defined impact region on the same event and each group come back with a very different set of results and conclusions. This is partially because of the assumptions upon which economic impact analyses rest, and can be manipulated unethically to meet the needs of those conducting the study. "Changes in the assumptions used can lead to dramatically different impacts being identified, and economic impact analysis should be viewed as an educated guess" (p. 17). This can also occur because errors may stem from misunderstanding of the economic impact concepts or could be a deliberate misrepresentation (Crompton, 1995). 
Several errors made while conducting and interpreting economic impact studies stem from the misapplication or misinterpretation of multipliers and the multiplier effect, which is the principal economic theory in economic impact studies. "Basically, the multiplier recognizes that changes in the level of economic activity created by visitors ... bring changes in the level of economic activity in other sectors and, therefore, create a multiple effect throughout the economy" (p. 18). For example, a group of spectators from other areas travel to a city to see their favorite sports team in the playoffs and spend $\$ 10,000$ in that community through lodging, food, entertainment, and transportation (Crompton, 1995). "This concept recognizes that when visitors to an event spend money in a community, their initial direct expenditures stimulate economic activity and create additional business turnover, personal income, employment, and government revenue in the host community" (Crompton \& Lee, 2000, p. 114). This ripple effect of expenditures is termed a "multiplier" and shows the spread of money through the local economy (Crompton \& Lee, 2000).

Misrepresentation of employment multipliers can lead to misleading results from an economic impact study in regards to estimated number of jobs created because of visitor expenditures. "The employment multiplier measures the direct, indirect, and induced effect of an extra unit of visitor spending on employment in the host community. It shows how many full-time equivalent job opportunities are supported in the community as a result of visitor expenditure" (Crompton, 1995, p. 22).

Employment multipliers can be very misleading since many times employers will not hire more staff due to an event or festival and will, for example, have current employees work overtime or ask that all staff work certain days that they normally would 
be off duty. Additional demand created by something like a festival may be met by greater utilization of the existing workforce as opposed to increasing the level of employment in that community (Crompton, 1995). A potentially misleading aspect of employment estimates is that they may imply that all new jobs will be filled by community residents (Crompton \& Lee, 2000). This can be misleading because it's possible that a number of these jobs will be filled by individuals commuting from outside that community. This would make it inappropriate to come to the conclusion that all the jobs benefit the community's residents (Crompton \& Lee, 2000).

Using the incorrect multiplier or incorrectly determining the multiplier can lead to large differences in the final outcome. "By not understanding how multipliers are derived or using the wrong multiplier, decision makers could reach false conclusions" (Crompton, 1995, p. 24). The incremental approach to determining multiplier coefficients indicates that if $\$ 1$ of direct income is created, then a proportion of other income will be created in various other areas of the economy. This method does not include information on the size of the initial leakage (taxes, etc.) and because of this does not give a true indication of the impact (Crompton, 1995).

Failing to define the area of interest accurately can create a large discrepancy between the reported and the actual impact. Individuals giving information on their expenditures must know where the boundaries of the impact region lie. If this is not clearly defined, reporting on expenditures may be incorrect. Not clearly defining the region under study can also lead to inaccurate multipliers which can misrepresent economic impacts of an event in that region. "Changes in geographical boundaries of the area of impact are likely to lead to changes in multiplier size, because the magnitude of 
the multiplier depends on the structure of the host community" (Crompton, 1995, p. 25). It is generally assumed that a smaller community tends not to have "sectorial interdependencies" which aids a community in retaining monies spent in the first round of expenditures. There are fewer links holding the money in that small community. A community that would be considered small is more likely to have to spend its money outside of its boundaries because of non-production of goods and services within that small community. For example, a small fishing community may sell some of its goods elsewhere while purchasing other items and services such as dairy products and boats from outside communities. Through this exchange of goods and services, the small fishing community can gain what could not be generated within its boundaries.

It is crucial that the expenditures within the defined area be the only ones included and not total visitor expenditures representing expenditures made outside of the defined impact region (Crompton, 1995). An individual may purchase a plane ticket, rental car, gasoline, lodging, and food while traveling to an event, but this could all be purchased outside the boundaries of the region housing the event. Many times, as in the case of large scale festivals or concerts, individuals may stay in a hotel, eat, and do other activities away from the event site either to avoid traffic congestion or because lodging or other services are booked up or are otherwise unavailable.

Including local residents or spectators is incorrect when attempting to estimate the economic impact. Expenditures made by individuals residing within the impact region's defined boundaries does not represent the circulation of new money within that area, instead it represents a recycling of money that already existed in the area. It is reasonable to assume that if residents had not spent money on this particular event, they would have 
eventually spent that money on some other good or service within the community. This means the expenditure associated with the event or venue under question is likely to be "switched spending" which offers no net economic stimulus to the community and should not be counted as economic impact (Crompton, 1995). "Economic impact attributable to a sports event relates only to new money injected into an economy by visitors, media, external government entities, or banks and investors from outside the community. Only spectators who reside outside the jurisdiction and whose primary motivation for visiting is to attend the sports event, or who stay longer and spend more because of it, should be included" (Crompton, 1995, p. 26). Including local residents generates extremely high numbers and may be used by advocates of the event or facility as a way to deliberately mislead people in order to boost their advocacy position (Crompton \& Lee, 2000). Individuals labeled as "time-switchers" and "casuals" should not be included in an economic impact assessment. A "time-switcher" is an individual who would have traveled to an area without the presence of the event, but the event was a reason that influenced their decision to come during that time. Casuals "are visitors who were already in the community, attracted by other features, and who elected to go to the event instead of doing something else" (Crompton \& Lee, 2000, p. 113). Inclusion of "timeswitchers" and "casuals" would lead to a greater impact than truly exists in regards to the impact of large scale events such as festivals like Springfest, Sunfest, and Winterfest in Ocean City, Maryland (Lee, 2003). When looking at large scale events such as these, to truly estimate the economic impact, only individuals who traveled to the area for the festival should be included. Otherwise, the results will be inflated. "Expenditures by 'casuals' and 'time-switchers' would have occurred without the event, so income 
generated by their expenditures should not be attributed to it" (Crompton \& Lee, 2000, p. $113)$.

"Time-switchers" and "casuals" don't necessarily apply in the camp setting because a "time-switcher" would be an individual who may have originally planned to attend camp during the second week, but changed their plans to attend during the fourth week instead. They would still contribute approximately the same amount to the community while traveling to and from the camp, regardless of what week they camped, unless there was an event or other consideration that led to the time-switching and would affect their expenditures, but then at least part of those expenditures would be attributed to the event or other consideration. For example, if parents were going to drop off their kids during week two, but later discovered there was going to be an antique show in the area on the first day of week four and changed their child's week at camp in order to attend this show, that would represent a time-switch. Also, because antique shows generally lead to the making of large expenditures, the reported expenditures for that trip would be larger than normal and would be because of the antique show. A "casual" in this setting would be an individual who had already traveled to the area and came across the camp and decided to attend, which would be very rare since many residential weeklong camps, including Camp Henry, utilize pre-registration.

Multiplier coefficients calculated for one impact region should not be used in another. Every situation and host community must be analyzed and assessed separately since the combinations of business interrelationships in each community are structured differently, leading to changes in linkages and leakages from one community to the next. When the results from one community's economic impact assessment are taken and 
applied to another, even if the communities are similar, this will misrepresent the impact (Crompton, 1995).

A study changes from an economic impact analysis to a benefit-cost analysis if benefits are measured while not incorporating costs. Many times only the positive economic benefits associated with visitors to an event or venue are reported and the costs or negative impacts inflicted on the host community are not considered (Crompton, 1995). "An economic impact analysis is designed to study the economic effect of additional expenditure attributable to a sports event and should be compared with equivalent investments designed to create economic stimulus in other sectors of the economy. In contrast, benefit-cost analysis is designed to identify the most sensible investment alternative. It considers the long-term benefits that can be obtained from the sports investment, identifies the long term costs, and compares the net benefits with those likely to accrue if the same resources were employed in other options" (Crompton, 1995, p. 33). Other cautions regarding economic impact studies that should be mentioned, but are not relevant to this study, include claiming total instead of marginal benefits, confusing the turnover with the multiplier, and omitting opportunity costs (Crompton, 1995).

Crompton (1995) describes criticism on many fronts about the use of multipliers and economic impact studies as a tool for legislative decision-making. Some say that multipliers overstate the economic benefits of many industries (sports stadiums were specifically mentioned) and their benefit to the host community. The use of economic impact studies to encourage government decision makers to unwisely invest taxpayers' money has also been a criticism against these types of studies, but Crompton states that 
"despite its weaknesses and limitations, economic impact analysis is a powerful and valuable tool if it is implemented knowledgeably and with integrity" (p. 34).

Clearly the reported results from economic impact studies should be viewed with a critical eye. Results can be manipulated by individuals trying to meet their own needs and trying to make grandiose claims of the economic prosperity that will result from what they are supporting. There are many ways to misinterpret or misapply these concepts, as shown above. Crompton (1995) compiled the following list of the eleven most common misinterpretations and misapplications of economic impact studies; using sales instead of household income multipliers, misrepresentation of employment multipliers, using incremental instead of normal multiplier coefficients, failure to define the area of interest accurately, inclusion of local spectators, failure to exclude "time-switchers" and "casuals", use of "fudged" multiplier coefficients, claiming total instead of marginal economic benefits, confusing turnover and multiplier, omitting opportunity costs, and measuring benefits only while omitting costs. The following sections review studies conducted in the field of recreation, parks, and tourism, delves more specifically into parks and campgrounds, and concludes with a discussion of resident camps.

\section{Economic Impact of Tourism, Large Scale Events, and Sports Facilities}

"In many communities, tourism is recognized as an important contributor to economic development, but the central role of park and recreation agencies in creating tourism business is frequently overlooked" (Crompton \& Lee, 2000, p. 108). In the recreation, parks, and tourism industry, justification for an event or venue is often needed to gain support from possible host communities for that venue. Community residents “... 'give' funds to their city council in the form of taxes. The city council uses a proportion 
of these funds to subsidize production of an event or development of a facility. The facility or event attracts nonresident visitors ...”(Crompton \& Lee, 2000, .109). The nonresident visitors make expenditures within the local host community, both inside and outside the facilities and events they visit (Crompton \& Lee, 2000). Income and jobs are created for residents in the community with this new money. The cycle is completed when community residents receive the return of new jobs and additional household income from their initial tax investment (Crompton \& Lee, 2000).

It is not uncommon for supporters of new sports facilities to ask for economic impact studies to be conducted with the intent of rallying support for building a new sports arena or stadium. "The most prominent type of economic impact presented by facility advocates invariably is the economic impact of money spent in the community by users of the facility-spectators, vendors, media, teams, etc." (Crompton, 2004, p. 42). The results of independent economic impact studies evaluating large major league sports facilities, free from a commissioning sponsor, can be discouraging. Some of the reasons behind why these facilities may not stimulate a large amount of economic activity could include the fact that many facilities are independent of the local vendors, instead of being interwoven with stores and restaurants in the area. Many stadiums are "designed for quick entry and exit of suburban fans with automobiles" (Crompton, 2004, p. 47). While economic impact from a major league sports facility may not directly generate as much money in a local economy as one would hope, there are other factors, such as increasing the community's visibility, enhancing the community's image, stimulating other development in the area, and "psychic income" (Crompton, 2004). That last term refers to the fact that when a sports team comes to a city, a broad segment of the population 
becomes excited and can identify with that team. "A sports team is an investment in the emotional infrastructure of a community... They are one of the few vehicles available for developing a sense of community" (Crompton, 2004, p. 49). This "sense of community" could also lead individuals to purchase such items as team jerseys, team blankets, license plate frames, bumper stickers, and other accessories that the community member would not have purchased otherwise.

A review of the economic impacts of 14 sports tournaments (Crompton \& Lee, 2000) discovered that the two tournaments with the smallest economic impact on their communities were both one-day events. "If an overnight stay is not required, then the economic impact on the community is likely to be small" (p. 119). Also, these sports events did not appear to be "sufficiently extensive or prestigious" to attract out-oftowners and relied mainly on local clientele. As stated before, the economic impacts of tourism include the sales, employment, and income resulting from the expenditures of non-local visitors in local businesses (Johnson, Obermiller, \& Radtke, 1989). Expenditures by community residents do not contribute to an actions economic impact. These expenditures represent a recycling of money, not an influx of new funds from outside the region. "It is probable that if local residents did not spend this money at the tournament or event, then they would have disposed of it either now or later by purchasing other goods and services in the community" (Crompton \& Lee, 2000, p. 112). Thirty dollars spent by a group of friends (who all reside in the area) on a community theater production is likely to be thirty less dollars spent by that group of friends elsewhere on movie tickets, concert tickets, or other entertainment in the community. 
This switched spending "offers no net economic stimulus to the community" (Crompton \& Lee, 2000, p. 112).

Tourism can be a large contributor to regional economies. "In response to the need for diversification, many regions have attempted to develop their tourism industry as a complement to their traditional economic base" (Johnson, et al., 1989, p. 140). Tourism and adventure tourism, such as humpback whale watching in Tonga (Orams, 2002) or jungle canopy zip-line tours and white water rafting trips in Costa Rica, have been developed by local industry to help boost the respective economy. Visitors would most likely shop and dine in these locations, but the added novelty of these tourist attractions may bring more people to the area and may encourage those people to spend more money in that economy. This may show the potential for economic impact that added tourism venues could have on a specified region.

\section{Economic Impact of parks and campgrounds}

Loomis (1989) estimated the economic activity generated by visitors to public parks and other outdoor recreation areas in California. The purpose was "to quantify what is known about the tangible economic benefits of public parks and outdoor recreation areas ..." (p. 56). By studying the economic benefits of public parks and outdoor recreation areas, Loomis was able to present tangible results which aid in the justification of outdoor recreation areas being present in a community and help to rally support for these areas. Elected officials and community decision makers have voiced opinions expressing that park land and open space are costly investments "from which a community receives no economic return. The social merit of such investment is widely accepted, but social merit amenities frequently are regarded as being of secondary 
importance when budget priorities are established" (Crompton, 2001, p. 2). This applies not only to open spaces and park land, but to campgrounds and camps as well.

"Visitor expenditures in and around a park are a source of growth within the local regional economy" (Dawson, Blahna, \& Keith, 1993, p. 51). Outdoor recreation, including the use of parks and campground facilities, can have a large impact on local industry. "Public lands receive over a billion recreation visits each year. Recreational uses provide benefits to the visitor and also create economic impacts in nearby communities" (Stynes, 2005, p. 1).

State expenditures on parks have been decreasing, meaning that the parks themselves must generate funds. "In real dollar terms, states' aggregate budgets increased by $47 \%$ during the decade (1989/99-1999/2000), while their expenditures on parks and recreation increased less auspiciously by 26\%" (Crompton \& Kaczynski, 2004). Although $26 \%$ is a substantial increase, it does not match the growth in total state budgets. A small percentage difference can mean large monetary differences. For example, Texas' investment in parks and recreation in 1990 was 3.1\% and dropped down to $1.3 \%$ by the year 2000 . If Texas had kept its $3.1 \%$ share of the state budget, its funding would have been $\$ 137$ million in the year 2000 instead of its actual funding of $\$ 55$ million (Crompton \& Kaczynski, 2004).

The impact to local economies will be greater the more self-sufficient a local industry is in meeting park and visitor demands (Loomis, 1989). If visitors can find what they need within the areas surrounding a park or outdoor recreation area, the money they spend will stay within that local economy. If visitors have to leave the area to eat, find 
lodging, or to find other goods and services, those expenditures will go elsewhere instead of being spent within the host community.

Donnelly, et al. (1998) discuss how the extent to which a park facility is developed influences the amount spent by the visitor. One example included undeveloped backcountry parks where there are few facilities and few opportunities for visitors to spend money. Other natural resource areas may contain many facilities where goods and services could be purchased, such as lodges, restaurants, or boat rental docks. The state parks that have the greatest employment impact of state park expenditures are ones with an "intermediate level of development" (Dean, et al., 1978, p. 98). State parks with this level of development have enough facilities available to attract non-resident visitors, but not so much that they are self-sufficient and independent of the local business sector (Dean, et al., 1978).

A highly developed venue that is almost completely independent of the surrounding area will have little to no impact on the local economy. An example of a venue with a high level of development would be something similar to a large theme park with a hotel for guests to stay, restaurants for them to dine in, and amusement rides to entertain individuals of all ages encompassed within the same area. This leaves little reason for guests to leave the theme park grounds, whereas a venue with amusement rides and food services but no lodging would lead guests to leave the venue for lodging and possibly meals while traveling to and from the venue as well.

Another aspect of economic impact, besides the money spent in the impact region, is the creation and support of jobs because of that venue. Dean, et al. (1978) suggested that, as a secondary effect of direct park spending, a little less than 1 job outside of the 
park was created for every 10 jobs within the park, and that in general 1 additional job was created for every 6 park jobs by park visitor expenditures. Visitors to a park may not realize the extent to which they are supporting the surrounding community. The money they spend while traveling; at gas stations, restaurants, retail outlets, bridge tolls, and much more, can lead to many jobs within the host communities.

If the quality and number of public outdoor recreation areas can be improved within a specified state, residents of that state may not leave to vacation elsewhere and this may also attract more vacationers from other states (Loomis, 1989). If area residents vacation within their state and more out-of-state visitors are attracted to an outdoor recreation area, the potential for economic growth increases. "The expenditures of state park visitors (e.g., gasoline, lodging, groceries) in a local region represent sales to businesses (i.e., direct effects)" (Loomis, 1989, p. 60). Indirect effects of these expenditures could include a businesses's use of this income to pay employee salaries or to purchase additional goods and services (Donnelly et al., 1998). Not all of the visitor dollars that are initially spent remain in the local economy. When money is spent outside of the impact region to purchase products and services needed to support the recreation industry, "leakages" occur (Loomis \& Walsh, 1997).

A study on the economic impact of visitation to Pomona State Park in Kansas used four categories to collect data on expenditures. The categories used included "triprelated expenditures made at home before the trip" such as the purchase of sunscreen, "expenditures made while traveling to and from the site" such as the purchase of gasoline, "expenditures made while at the site or in the immediate vicinity of the site" such as the purchase of souvenirs or meals, and lastly "annual expenditures on recreation 
equipment" such as that spent on boat or other equipment maintenance (Cordell, et al., 1992). The authors stated that if this park were to shut down, the economic activity found in the impact region would likely be eliminated. This is assuming there are no other parks in the impact region that would be found by visitors to be superior to substitute parks outside the region. Nonresidents would most likely reallocate their recreational trips to outside parks, thus transferring their spending outside of the impact region (Cordell, et al., 1992). There could be a "shock" to the local economy depending on how directly residents would reallocate their expenditures among other businesses within the impact region.

Donnelly, et al. (1998) found that state parks are significant contributors to local economies. This study of four Colorado state parks and the effect those parks have on the rural county host economies supports previous research about the contributions of state parks. This study found that, although individual contributions by park visitors were low, the cumulative effect of park visitor spending was substantial. "Visitors repeatedly commit both money and time to participate in outdoor recreation" (Loomis, 1989, p. 57). Park visitors as individuals may not spend large amounts of money, which is why they may be looked at as unimportant to a community's economy, but as a group they contribute largely to the community.

Besides expenditures in a local economy, recreation sites can have significant influence over property values. "The premise that parks and open space have a positive impact on property values derives from the observation that people frequently are willing to pay a larger amount of money for a home located close to these types of areas, than they are for a comparable home further away" (Crompton, 2001, p. 2). Property next to 
active recreation facilities had slightly lower values than property next to parks with natural landscapes, which has been attributed to the fact that property next to recreation facilities are exposed to more noise and pedestrian traffic than natural landscapes (Crompton, 2001).

Dawson, Blahna, and Keith (1993) suggest three possible approaches for communities looking to increase the economic benefits derived from the presence of a national park, such as Great Basin National Park. Increasing the number of visitors, increasing visitor expenditures, and increasing the amount of time visitors stay in the local area are three suggestions for the Great Basin area that can be applied to similar communities elsewhere. Although these approaches could bring more funds to an area, the negative effects of these varying approaches must be considered as well. Increased visitation could be detrimental to a park or other natural resources, local infrastructure, and local resident sentiment (Dawson, et al., 1993). Increasing visitor expenditures and extending the length of stay create less stress on a resource than increasing the number of visitors. "By broadening the scope of interpretive programs and activities offered at the park, visitors could be enticed to stay longer in the area" (Dawson, et al., 1993, p. 55). The more programs or other points of interest, the more likely an individual is to stay and spend both time and money in that location.

\section{Economic Impact in the Camp Setting}

The previous studies conducted about large scale events, festivals, open spaces, parks and campgrounds, open the door for research to be conducted on the economic impact of a residential summer camp. Although this study did not meet the criteria 
required to be termed an economic impact study, recommendations for how to properly conduct a future study are part of the discussion in Chapter Five.

\section{Summary}

Regional economic impact studies estimate the changes in a region's economic activity resulting from an action, which can be anything from the designation of a park or open space, to building a sports stadium, to harvesting timber (Stynes, 2005), or

constructing a residential camp. Each action has the possibility of bringing money to or generating revenue within, its region (Stynes, 2005).

An economic impact study is based on numerous criteria which are often misused, overlooked, or abused by the researcher or by the individuals interpreting the results (Crompton, 1995). Misapplications and misinterpretations of economic impact studies include using sales instead of household income multipliers, misrepresentation of employment multipliers, using incremental instead of normal multiplier coefficients, failure to define the area of interest accurately, inclusion of local spectators, failure to exclude "time-switchers" and "casuals", use of "fudged" multiplier coefficients, claiming total instead of marginal economic benefits, confusing turnover and multiplier, omitting opportunity costs, and measuring benefits only while omitting costs (Crompton, 1995).

Large scale events and sports facilities can be recognized as actions that will generate revenue within a host community, but this is not always the case. Many sports facilities are independent of local businesses and do not bring visitors to the stores and restaurants in the area (Crompton, 2004). Events lasting one day, where no overnight stay is required, do not generate much economic activity within the host region (Crompton \& Lee, 2000). 
Loomis (1989) studied visitor expenditures when visiting public parks and outdoor recreation areas in the state of California. Loomis was able to present tangible results which were used to justify the presence of outdoor recreation areas within communities and to help gain support for those areas. It was found that the impact to local host communities would be greater the more self-sufficient local businesses were in meeting visitor demands (Loomis, 1989). In addition to revenue generated within the region, the creation and support of jobs within that region holds great value to community members and local industry (Dean, et al., 1978).

Evaluating the economic impact of a festival, sports arena, outdoor recreation area, state park, campground, camp, or other venue on its host community can be valuable for the host community, potential host communities, and for similar communities elsewhere. These studies established the criteria and concepts needed to expand the research base to actions such as residential camps. 


\section{CHAPTER 3}

Methodology

This chapter details the methodology used and includes information about the setting, site, sample population, instrument selection and design, and the pilot study. It also includes the data collection procedure, the coding used, and describes the method of data analysis. Data were collected from participants through a self-administered questionnaire during check-in at the beginning of weeks three, seven, and eight of the eight week long summer camp season.

\section{Setting}

Camp Henry is a traditional residential summer camp located in Newaygo County in western Michigan. Newaygo County is a rural area that is divided into 24 townships and 4 cities (Newaygo County Government website, 2006). The county includes the town of Newaygo and the surrounding areas of Fremont, Grant, White Cloud, Hesperia, Brohmna, and Bitely. Newaygo County has a total area of 861 square miles $(2,231$ square kilometers); 842 square miles of the county is land and 49 square miles is water (Newaygo County Government, 2006).

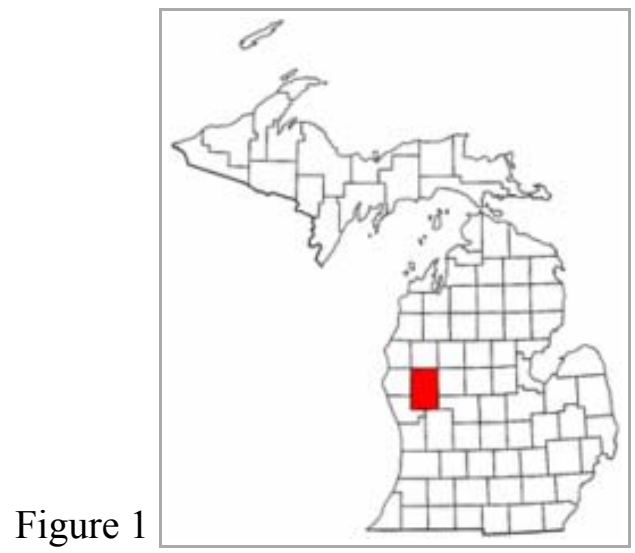


According to the U.S. Census Bureau, the population of Newaygo County as of the year 2010 was 48,460 individuals; $50.3 \%$ male and $49.7 \%$ female. There were 18,406 total households; 13,162 of which are families (Factfinder, 2012). Approximately $94.1 \%$ of county residents describe themselves as Caucasian, $5.5 \%$ describe themselves as Latino or Hispanic, and the remaining percentages of residents describe themselves as Black or African American, Native American, Asian, and Pacific Islander. Approximately one-quarter of the 18,406 households had children under the age of 18 residing with them. Approximately $28.5 \%$ of households were non-families; non-related individuals residing together in the same living space. The average household size was 2.60 individuals and the average family size was 3.04 individuals. The median age of Newaygo County residents in 2010 was 40.9 years (Factfinder, 2012).

\section{Site}

Camp Henry is located on the shores of Lake Kimball in Newaygo County, Michigan. The camp is 35 miles north of Grand Rapids, Michigan, where the Westminster Presbyterian Church of Grand Rapids is located. This church established Camp Henry in 1937 to provide a wholesome Christian outdoor experience for young children. Today, Camp Henry's main goals are to "serve the child, the individual, the family, the church and the community through year-round programs of children's camps, family camps, conferences and retreats" (Camp Henry, 2006).

Activities offered to campers at this location include horseback riding, waterskiing, wakeboarding, tubing, kayaking, canoeing, arts and crafts, science and exploration, hiking, and rock climbing (Camp Henry, 2006). There are three challenge courses that offer both high and low elements for participants. Camp Henry offers spring 
and winter retreats for college and corporate groups, school programs and environmental education, as well as summer camp. While Camp Henry operates year-round, this study focuses on the economic impact during the course of the 2005 summer camp season.

\section{Population of Interest}

This study focuses on summer camp patrons of Camp Henry. These patrons are individuals with at least one child in their household who attended Camp Henry during the 2005 summer camp season. By studying this population and the amounts and types of expenditures made in different categories we may find information valuable to local community leaders, county residents, vendors, camp professionals, and the camp itself.

\section{Sample}

The sample was selected through a non-probability purposive random cluster drawing, where each week is classified as a "cluster". The sample was composed of adults delivering campers to Camp Henry in Newaygo County, Michigan. Questionnaires

were distributed at the beginning of weeks three, seven, and eight (July $3^{\text {rd }}$, July $31^{\text {st }}$, and August $\left.8^{\text {th }}, 2005\right)$ of the eight week long summer camp program. These weeks were selected through a purposive random cluster selection process, with each week (one through eight) being a cluster. A purposive sample is a "non-probability sample chosen when individuals considered most closely related to the issue being studied are selected for inclusion" (Mitra \& Lankford, 1999, p. 300). Pieces of paper with weeks one through eight written on them were put into a drawing and were randomly selected to minimize sample bias. 


\section{Instrument Selection}

A self-administered questionnaire was chosen as the method of data collection. This method was decided upon because of the ease with which it could be administered and completed by the respondents. “...(S)ite-specific demand models often use park visit data or on-site visitor surveys" (Stynes, 2005, p. 3) and because of the atmosphere of the location where collection occurred, the camp check-in line. Most other instruments of data collection would have been much more difficult to administer and would not have suited the purpose of this study as well.

\section{Instrument Design}

The front page of the questionnaire, as seen in Appendix A, shows the Camp Henry logo, provides directions for completing the questionnaire, displays a map of Newaygo County with a list of the towns included within the county's boundaries, and describes the purpose of the study. This page includes a map of Newaygo County and references the immediate surrounding counties in order to provide participants with the ability to accurately account for expenditures within the county.

The second page of the instrument is the "informed consent" form, approved in 2005 by the Human Resources Committee at California Polytechnic State University, San Luis Obispo. By completing the questionnaire, participants give their consent to be included in the study. The form (Appendix A) lists information such as; the purpose of the study, who was conducting the study and affiliation, how long it would likely take to complete the questionnaire, and contact information for the participants who may want to contact the researcher or receive a report of the findings. 
Page three requests information about the amount of money spent by the respondent and their group on the way to Camp Henry to drop off their camper(s) and a separate section for the estimated amount they would spend when they pick up their camper(s). The questionnaire asks the participants to report their groups expenditures in the areas of lodging, food and beverages, private auto expenses, retail shopping, recreational activities, and any other expenses they may have had in an open ended list where they were able to fill-in the amount. These categories were modeled after the categories used in an economic impact study of the Springfest Festival in Ocean City, Maryland (Crompton, Lee, \& Shuster, 2001).

A separate list of the same expenses is provided to report estimated expenditures for the return trip. The instrument includes a demographics section with close-ended questions to determine the gender, marital status, annual family income of the participant, and a "yes" or "no" box asking if it is the first summer their camper(s) attended Camp Henry. Four open-ended questions are included to determine the age of the participant, number of people traveling in their group, their hometown, and the zip code in which they reside.

\section{Pilot Study}

The first version of the questionnaire was tested for clarity and usability to make sure the instrument was appropriate for participants in both content and reading level. Preliminary versions on the instrument were sent via email attachments to five reviewers working in the camp industry and members of the American Camp Association's Committee for the Advancement of Research and Evaluation. Email feedback was received and appropriate changes were made. Four reviewers personally known by the 
primary investigator tested hard copy versions of the questionnaire. Appropriate suggestions for improvement were discussed and appropriate revisions were made to the instrument.

The suggested revisions included changing the "family's annual income" range. The original instrument had a range of "less than 10,000 " to " 100,000 or greater." The higher end option was changed to have the maximum of "200,000 or greater." A map of Newaygo County, MI was included in the revised version of the questionnaire with the intent to help respondents determine if they did or did not make purchases within the boundaries of Newaygo County.

\section{Data Collection Procedure}

The participant data were collected at the beginning of weeks three, seven, and eight. Questionnaires were distributed to participants via clipboards with pens attached while waiting in line to check their campers in at the start of the camp session. Upon completion of the questionnaire, individuals were asked to pass the clipboard to the next person in line. If that person was unwilling to complete the questionnaire, they were asked to pass it to the next willing individual.

\section{Data Coding}

Written responses to the instrument were coded in order to analyze the data. The first set of data were on reported expenditures (see Appendix A for questionnaire); this data were entered just as the participant had responded, in dollar amounts. At the bottom of the third page was the statement "someone else will be picking up my camper," if checked or marked in any way it was coded 1 , if left blank it was coded 0 . Question four asked the respondent to indicate their gender; male was coded 1 and female coded 2. 
Question five asked the respondent to indicate their marital status; married was coded 1 and unmarried coded 2 (one written "widowed" response was included as a 2). Question six asked for the age of the respondent and was entered as the number reported, in years. Hometown was requested for question number eight and coded as follows; Grand Rapids was coded 1, Newaygo coded 2, other Michigan coded 3, and outside Michigan coded 4. Question nine requested the participant's zip code and was entered as the five digit number reported. Question number ten asked the respondent to check which income range represented their family's annual income, in $\$ 10,000$ ranges. There were 21 income ranges which were coded 1 to 21 . These ranges were later collapsed to make data analysis less complicated and to allow for more meaningful comparisons between groups. The last question, number eleven, asked if this was the first summer the camper had been to Camp Henry; "yes" was coded 1 and "no" coded 2.

\section{Data Analysis}

The following topics were explored and evaluated through the analysis of responses to the self-administered questionnaire. The results, found in Chapter Four, were calculated using the computer programs Minitab and Microsoft Excel.

"Hometown" was divided into two groups; Newaygo County area residents and Grand Rapids area residents as one group and other Michigan area residents and outside of Michigan area resident as a second group. The groups expenditures were compared to see if any statistically significant differences existed between them.

"Income level" and the logarithm of participant expenditures was analyzed to determine if an individual's yearly income level had an statistically significantly effect on expenditures while traveling to and traveling home from Camp Henry. 
The variable of "age" and the logarithm of expenditures was analyzed to determine if an individual's age had any statistically significant effect on their expenditures. This was to determine if any particular age group spent differently than other age groups while traveling to and from the residential camp site.

"Previous camp experience" was divided into two groups; those who had attended Camp Henry before and those who had not previously attended. The expenditures of the two groups were compared to determine if there was a statistically significant difference. This was to evaluate if individuals who had camped at Camp Henry before spent significantly more or significantly less while traveling to and returning home from camp than individuals who had not previously camped there.

\section{Summary}

Camp Henry is a traditional residential summer camp and conference center located on the shores of Lake Kimball in rural Newaygo County, Michigan. This study focuses on expenditures made in the categories of lodging, food and beverage, private auto, retail shopping, recreational activities, and "other" by summer camp patrons traveling to and from Camp Henry during the 2005 summer. The sample was selected through a non-probability purposive random cluster draw. Data were collected on arrival days of weeks 3, 7, and 8 through the use of a self-administered questionnaire, shown in Appendix A. The pilot study included members of the American Camp Association's Committee for the Advancement of Research and Evaluation, among other evaluators. Data was coded to simplify the data analysis process. The data were analyzed to answer the posed research questions and is further addressed in Chapter 4. 


\section{CHAPTER FOUR Presentation and analysis of the data}

The findings of this study, including the analysis of the data and the presentation of the results, are reported in this chapter. Chapter 4 begins with descriptive statistics detailing the characteristics of the Camp Henry patron participants included in the sample, describes the breakdown of expenditures of camp patrons in the defined expenditure categories of lodging, food and beverage, private auto, retail shopping, recreational activities, and "other" and finishes with the results of the data analysis as they relate to the defined research questions posed in Chapter 1.

\section{Participants}

Participants included individuals willing to fill out the self-administered questionnaire while waiting to check in their camper(s) on the arrival day of weeks 3,7 , and 8 of the 8 week long residential summer camp season. Week 3 yielded 15 participants, week 7 yielded 17 participants, and week 8 yielded 23 participants for a total of 55 participants for the study. Participant ages ranged from 18 to 54 years of age.

Reported group sizes ranged from 2 individuals to 6 individuals with the average group size being approximately 4 individuals (3.7). Table 1 displays participant characteristics including reported gender, marital status, hometown (as defined within the parameters of the study), and the number of first time campers and returning campers.

It is important to note, in Table 1, the number of participants residing in Newaygo and Grand Rapids, as those individuals reside within, or just outside, the impact region being studied. Upon analysis of the zip code data, shown in Table 6, some of the "other 
Michigan" respondents are closely located to the impact region, even though they are not residing within the Grand Rapids boundaries.

Table 1

Participant Characteristics

\begin{tabular}{lcc}
\hline Characteristics & Number & Percent \\
\hline Gender & & \\
Male & 15 & 27.3 \\
Female & 40 & 72.7 \\
Marital Status & & \\
Married & 43 & 78.2 \\
Unmarried & 12 & 21.8
\end{tabular}

Hometown

Grand Rapids $\quad 28 \quad 50.9$

Newaygo $\quad 5 \quad 9.1$

Other Michigan $\quad 21 \quad 38.2$

$\begin{array}{lll}\text { Outside Michigan } & 1 & 1.8\end{array}$

First Time at Camp

$\begin{array}{lrr}\text { Yes } & 12 & 21.8 \\ \text { No } & 39 & 70.9 \\ \text { No Response } & 4 & 7.3\end{array}$

Table 2 titled "Participant Income Ranges - number of participants and average expenditures per group" presents the income ranges reported by participants, the number of participants reporting yearly earnings within each range, and the expenditures reportedly made by those groups on their way to and from Camp Henry during the summer of 2005. If no participants reported earnings within an income range, the expenditures were listed as "not applicable", as seen in Table 2.

The data in Table 2 show a broad spectrum of expenditure amounts and no trend or statistically significant differences between income groups. It is interesting to note that one participant listing themselves as making yearly earnings in the $\$ 30,000-39,999$ range reported expenditures of $\$ 160.00$, while participants listing themselves in the $\$ 200,000$ or greater range averaged only $\$ 59.63$. One participant in the $\$ 180,000-189,999$ range 
reported expenditures of $\$ 680.00$, the highest reported amount and were one of two participants reporting expenditures in the "lodging" category.

Table 2

Participant Income Ranges - number of participants and average expenditures per group

Reported Income

Less than $\$ 10,000$

$\$ 10,000-19,999$

$\$ 20,000-29,999$

$\$ 30,000-39,999$

$\$ 40,000-49,999$

$\$ 50,000-59,000$

$\$ 60,000-69,999$

$\$ 70,000-79,999$

$\$ 80,000-89,999$

$\$ 90,000-99,999$

$\$ 100,000-109,999$

$\$ 110,000-119,999$

$\$ 120,000-129,999$

$\$ 130,000-139,999$

$\$ 140,000-149,999$

$\$ 150,000-159,999$

$\$ 160,000-169,999$

$\$ 170,000-179,999$

$\$ 180,000-189,999$

$\$ 190,000-199,999$

$\$ 200,000$ or greater

No Response

Overall Average Number of Participants

0

5

\section{1}

1

3

6

6

4

3

4

0

0

1

2

1

1

1

1

0

8

7

55
Average expenditures per group

not applicable

not applicable

$\$ 40.00$

$\$ 160.00$

$\$ 20.00$

$\$ 26.67$

$\$ 78.83$

$\$ 42.50$

$\$ 69.38$

$\$ 20.00$

$\$ 118.75$

not applicable

not applicable

$\$ 165.00$

$\$ 215.00$

$\$ 99.00$

$\$ 120.00$

$\$ 95.00$

$\$ 680.00$

not applicable

$\$ 59.63$

$\$ 70.14$

$\$ 82.87$

In Table 3, the participants between the ages of 38-42 years of age appear to have reported potentially statistically significant higher expenditures than other groups, but this is due to an outlier reporting expenditures of $\$ 680$. No statistically significant differences exist between groups or between ages when variables are left as continuous. Data are not listed as continuous here for reporting purposes. There are few participants in the two lowest age ranges shown in Table 3, between 18 and 27 years of age, as most 
parents or guardians of children old enough to attend residential summer camp, within this population, are most commonly older than 18-27 years old.

Table 3

Participant age, number and average expenditure per group

\begin{tabular}{lcc}
\hline Age range & Number of participants & Average expenditure per group \\
\hline $18-22$ & 1 & $\$ 60.00$ \\
$23-27$ & 0 & not applicable \\
$28-32$ & 2 & $\$ 12.50$ \\
$33-37$ & 9 & $\$ 76.94$ \\
$38-42$ & 11 & $\$ 129.36$ \\
$43-47$ & 19 & $\$ 97.37$ \\
$48+$ & 12 & $\$ 25.58$ \\
No answer & 1 & $\$ 200.00$
\end{tabular}

\section{Analysis of Research Questions}

1) What types of expenditures were made and how much was spent by patrons traveling to and from Camp Henry during the 2005 summer?

Types of expenditures made include lodging, food and beverage, private auto, retail shopping, recreation activities, and other expenditures. Data was reported in each category on the instrument, meaning that each type of expenditure was made by at least one participant of the study on their way to or from Camp Henry. Total expenditures for the 55 respondents and the individuals traveling with them came to $\$ 4,558$. Average per person expenditure, taking into account the number of individuals included in each party (206 individuals), totaled \$22.13.

Table 4

Total and mean group expenditures by category

\begin{tabular}{crc}
\hline Category & Total & Mean per group $(\mathrm{n}=55)$ \\
\hline Food & $\$ 1,645$ & $\$ 29.91$ \\
Auto & $\$ 1,381$ & $\$ 25.11$ \\
Shopping & $\$ 778$ & $\$ 14.15$ \\
Recreation & $\$ 360$ & $\$ 6.55$ \\
Other & $\$ 214$ & $\$ 3.89$ \\
Lodging & $\$ 170$ & $\$ 3.09$
\end{tabular}


The category of greatest expenditure, seen in Table 4, is food and beverage totaling $\$ 1,645$ for the 55 groups. The category of least expenditure, lodging, totaled $\$ 170$ with just 2 participants listing expenditures in that category. Of those 2 participants, one reported traveling in a party of 4 individuals and spending \$50 on lodging while the other participant reported traveling in a party of 2 individuals and spending $\$ 120$ on lodging.

2) Do first time campers spend significantly more amounts of money while traveling to and returning from Camp Henry than returning campers?

The data from this sample is right skewed. In order to analyze the data and meet the requirements of the analysis, a bell shaped curve is needed. To achieve a more bell shape than the data presents, the expenditure data was transformed to a logarithm base 10 scale. With the logarithm scale, the data takes on a much more bell shaped appearance and meets the requirements of an Analysis of Variance test.

A one-factor ANOVA was run with the logarithm of the total expenditures comparing first time camper groups and returning camper groups. With a $\mathrm{P}$ value of 0.077 , it is determined that there is no statistically significant difference between the groups at the 0.05 level. With the Tukey Method, the two groups were determined to be in the same letter grouping, meaning that there is not a statistically significant difference at the 0.05 level. After running the above tests, we see the data is borderline significant, but not significant. First time campers do not spend significantly more amounts of money while traveling to and returning from Camp Henry that returning campers. In fact, the 
near significant data show the opposite effect, with returning camper groups spending more than first time camper groups, but not at the statistically significant 0.05 level. 3) Does hometown, income, or age significantly affect the amount spent by Camp Henry patrons while traveling to and from the residential camp facility?

Reported hometown data are grouped together for analysis. Participants from Newaygo County and the neighboring city of Grand Rapids are one group and participants from other parts of Michigan and outside of the state are another group. A one-factor ANOVA was run with the logarithm of total expenditures comparing the two groups. With a $\mathrm{P}$ value of 0.101 , it is determined that hometown does not have an effect on patron expenditures at the 0.05 level.

Income data were coded categorically for the analysis. A regression analysis of the logarithm of the total expenditures and income categories was run and a $\mathrm{P}$ value of 0.626 was determined. Income does not have a statistically significant effect on patron expenditures.

A regression analysis was run with logarithm of the total expenditures and participant age. The $\mathrm{P}$ value was 0.574 . No statistically significant relationship exists between a participant's age and the amount spent.

Table 6 reports the data collected regarding hometown zip codes of the participants. The top ten most reported codes are listed in the table along with the count and percentage of participants reporting to reside within those areas. The zip codes 49505. 49506, 49507, 49546, and 49544 correspond to the city of Grand Rapids, Michigan. The code 49525 corresponds to Northview, Michigan, located 35 miles from Newaygo. The code 49421 corresponds to Hesperia, MI (within Newaygo County limits). 
The code 49331 corresponds to Lowell, Michigan located a few miles East of Grand Rapids. The code 48348 corresponds to Clarkston and the Independence Township, approximately a 3 hour drive from Newaygo County. The code 48306 relates to Rochester, Michigan, approximately a 3.5 hour drive from Camp Henry (Mapquest, 2012).

There were 20 participants who reported zip codes that no other participant reported. These individual codes represent $36.2 \%$ of the data reported. The zip codes listed in the table below represent $63.8 \%$ of participants and are in order of most to least frequently reported.

Table 5

Participant zip code frequency

\begin{tabular}{lcc}
\hline Zip code & Count & Percent of total participants \\
\hline 49506 & 9 & 16.36 \\
49505 & 5 & 9.09 \\
49525 & 4 & 7.27 \\
49421 & 4 & 7.27 \\
49546 & 3 & 5.45 \\
49331 & 2 & 3.63 \\
48348 & 2 & 3.63 \\
48306 & 2 & 3.63 \\
49507 & 2 & 3.63 \\
49544 & 2 & 3.63 \\
Remaining codes $(20)$ & 1 ea. & $1.81 \mathrm{ea}$
\end{tabular}

Displayed in Table 6 are the data regarding total expenditures by participants from each zip code and the expenditures per group. Since the make-up of the group is not known (the number of infants, children, and adults in each party) breaking the data down by number of groups, instead of individuals, is how the data were analyzed and interpreted. The column titled "total expenditures" is the grand total for all participants reporting to be from that zip code. The column titled "expenditures per group" is the 
grand total divided by "n", the number of participants who reported being from that zip

code.

Table 6

Participant zip code expenditures

\begin{tabular}{llcc}
\hline Zip code & $\mathrm{N}$ & Total expenditures & Expenditures per group \\
\hline 49506 & 9 & $\$ 214.50$ & $\$ 23.83$ \\
49505 & 5 & $\$ 360.00$ & $\$ 72.00$ \\
49525 & 4 & $\$ 180.00$ & $\$ 45.00$ \\
49421 & 4 & $\$ 405.00$ & $\$ 101.25$ \\
49546 & 3 & $\$ 150.00$ & $\$ 50.00$ \\
49331 & 2 & $\$ 845.00$ & $\$ 422.50$ \\
48348 & 2 & $\$ 630.00$ & $\$ 315.00$ \\
48306 & 2 & $\$ 81.00$ & $\$ 40.50$ \\
49507 & 2 & $\$ 30.00$ & $\$ 15.00$ \\
49544 & 2 & $\$ 120.00$ & $\$ 60.00$ \\
Remaining & 1 ea. & $\$ 1,542.00$ & $\$ 77.10$
\end{tabular}

Table 7 displays the data for each "hometown" category. Data were categorized into four groups; within Grand Rapids city limits, within Newaygo County limits, other Michigan locations, and outside of Michigan locations.

Table 7

Total and mean group expenditures by hometown

\begin{tabular}{crrc}
\hline Category & $\mathrm{N}$ & Total & Mean per group \\
\hline Grand Rapids & 28 & $\$ 1,234.50$ & $\$ 44.09$ \\
Newaygo County & 5 & $\$ 545.00$ & $\$ 109.00$ \\
Other Michigan & 20 & $\$ 2,693.00$ & $\$ 134.65$ \\
Outside Michigan & 2 & $\$ 85.00$ & $\$ 42.50$ \\
Total & 55 & $\$ 4,558.00$ & $\$ 82.87$
\end{tabular}

Presentation of the Results

No statistically significant relationships were found to exist within the data in regards to the research questions. In regards to research question one, as we see in Table 4, expenditures were reported in all categories with food and beverage being the category of greatest expenditure and lodging being the category of least expenditure. In regards to 
research question two, first time campers did not spend significantly more money while traveling to and from Camp Henry during the summer of 2005. In regards to research question three, hometown, income, and age do not have a statistically significant effect on patron expenditures.

\section{Summary}

Data were collected on arrival day of weeks 3,7 , and 8 of the 8 week summer camp season. A total of 55 individuals participated in the study. Participant ages ranged from 18 years of age to 54 years of age. Total expenditures for the participants came to $\$ 4,558$ with the category of greatest expenditure being food and beverage expenditures and the category of least expenditure being lodging expenses. First time camper groups and returning camper groups expenditures did not differ on a statistically significant level while traveling to or from Camp Henry during the 2005 summer. No age group, income level, or hometown showed statistically significant differences from the other groups in each category. The chapter that follows discusses the findings, implications for use, and recommendations for future research. 


\section{CHAPTER FIVE \\ Discussion of the findings and \\ recommendations for future research}

This concluding chapter addresses the data analysis and results presented in Chapter Four. A discussion of the possible uses of the findings is presented.

Recommendations regarding the instrument used, data collection, data analysis, and ideas for future research appropriate to the field are included in these final pages.

\section{Findings}

After running two one-factor ANOVAs and two regression analyses on the data utilizing the statistical computer program Minitab to determine whether statistically significant findings related to any of the three research questions exists within the data collected, no statistically significant relationships are found. Based on the analysis, there are no significant differences between any of the observed groups, such as first time campers and returning campers or when examining the expenditures of respondents of different income levels as compared to one another. The majority of Camp Henry patrons come to the site from a distance of approximately 35 (or fewer) miles away, which is a travel time of less than one hour by automobile. This means that the amount of time spent traveling, where products and services would likely be purchased, is very small. Few respondents report traveling long distances to deliver campers to the site. It is possible that those reporting data representing a camper traveling from a distance of more than 35 miles would not include the expenses as part of the respondent's travel to the site. This means responses are based on that day's journey and not the greater distance traveled by the camper, which possibly includes a plane ticket or other expenditures not included by the participant when completing the questionnaire. 


\section{Discussion}

No statistically significant relationships are present. The types of expenditures and the amount spent by participants are as expected. What is unexpected is the number of participants listing themselves as being from within or just outside the host community. Money flows into an impact area from visitors and that income is injected into the local economy (Loomis \& Walsh, 1997). Many participants would not require a visit to a gas station or to stop for refreshments during their travel to or from the site. Participants could consume a midday meal before driving the short distance to deliver their camper and return home with time to prepare and consume an evening meal, with no need for expenditures on food or lodging en route.

The consideration that first time campers potentially spend more on their way to and from the site than returning campers is evaluated. This concept is included in the research questions because of the thought that inexperienced, first time campers would not have packed all of the necessities for a week of residential camp. It is considered that, because of the novelty of restaurants and excursions, first time travelers to the defined impact region will spend more to experience these new things. The data does not reveal any such effect.

When variables are left as continuous, no significant relationships are found. Hometown, income, or age does not have a significant effect on the amount spent by patrons of Camp Henry.

\section{Implications for use}

Although the findings of this study cannot be used to determine the economic impact of a residential camp on its impact region or community, the body of residential 
camp research could benefit from a similar study that would do so. The findings would show the economic value of residential camps to their host communities and would aid these facilities in gaining funding support and allocation of land and other resources from governmental bodies or other funding sources.

A similar study would give a resident camp like Camp Henry the tools necessary to gain support from city planners, community members, and local vendors. These entities would then have reason to continue with or increase funding and resources for the action. If local vendors could calculate the amount of revenue a proposed project would generate, or current venue presently generates, the vendors would have monetary reason to show support for such projects. Events and venues would gain standing within the community if it appears as though revenues are maintained or increased for a business or service because of that action. Such a study acts as a tool for communities looking to build a residential camp or similar facility. A study like this would also help communities assess if a residential camp would be a viable option to generate more regional revenue.

A similar study would assist local businesses in organizing marketing campaigns aimed at residential camp populations. If data indicate that camp patrons purchase equipment immediately before their trip, advertisements in the area would be directed towards these individuals and draw them to purchase from a specific in-area vendor. Data showing that residential camp patrons consume midday meals in the area would lead vendors to purchase space on billboards and purchase other advertisement tools aimed at the camp going population. This type of information has the potential to shape a small business' marketing plan. Businesses relying on these traveling patrons would benefit 
from marketing techniques, drawing the population to utilize services and purchase goods from them, locally.

\section{Instrument Validity}

In regards to internal validity, the instrument was originally designed to collect data in order to measure the economic impact of Camp Henry's patrons on the defined region of Newaygo County, Michigan. The instrument properly measured participant expenditures in six categories while traveling to and from Camp Henry, which can be analyzed for relationships between expenditures and participants demographics, such as age or income level. Although an "economic impact study" did not result as originally planned because of the small sample size and being unable to utilize an analysis model that would include indirect and induced effects and multiplier coefficients, the instrument was valid in collecting the type of expenditure data desired.

In regards to external validity, the findings from this study will only apply to Camp Henry in Newaygo County, Michigan. Although the expenditure findings and relationships cannot be transferred to other impact regions, the greater concepts of the study can be applied to other residential camp settings. Regional multipliers dealing with that impact regions income, sales, taxes, and much more are calculated at the regional level and would vary across each study.

The instrument was determined to be appropriate for the participants surveyed, both in design and reading level, by members of the American Camp Association's Committee for the Advancement of Research and Evaluation. It was also determined to have been appropriate for the evaluation criteria being measured. During the pilot study, reviewers reported that the data collected would reflect what the researchers were 
attempting to evaluate and that the instrument questions directly reflected the research questions for the study.

\section{Instrument Usability}

The instrument is reasonably easy to administer and takes the average respondent approximately three to five minutes to complete. The written directions are consistent for

all participants and responses are not difficult to code and score. Many of the respondents completed the instrument while waiting in a bustling outdoor environment surrounded by children excited or anxious for the start of camp. This is not an environment conducive to quiet contemplation, but it was where the largest number of potential subjects would be available to researchers. The only other possible appropriate opportunity to have participants fill out the instrument would have been during a parent meeting on the first day after dropping off campers and before leaving the site. This meeting would most likely not attract parents of returning campers and holds the potential to bias the data. The sample size may have been increased using mail-in questionnaires, but both budget and time restrictions did not make this a viable option.

\section{Limitations of the methodology}

The methodology is limited in the following ways. The data collection procedure is biased towards respondents who can drive versus individuals who cannot. This data collection procedure may be biased against individuals who are physically unable to drive such as the blind, severely obese, or individuals who have another disability that prevents them from driving or traveling distances. It may be biased against individuals who do not have a driver license for the above reasons or any other reason. Non-drivers would not have driven their children to the residential camp facility via automobile on arrival day. 
Non-drivers could have ridden to the site with another family member or friend or asked other individuals to deliver their camper(s) to the site. Riding with a friend or family member would increase the size of the group traveling with the participant and would, therefore, have an effect on the data.

This study is biased against out-of-town parents. Out-of-town parents, like nondriver parents, would be required to send their child or children with another individual. This data collection procedure may be biased against divorced, sole-custody, or splitcustody parents who may not have been present to deliver their children to camp during this time period because of custody arrangements, visitation days, or other factors. This method of data collection may be biased against individuals traveling with very young children who would require attention and care while waiting in line.

The instrument requires that the participant report predicted expenditures for the return trip. This study is limited by the participants' inability to accurately predict the future. An individual cannot predict whether they will have automobile expenses such as a tow truck or an unexpected auto repair. Participants do not know at the time of data collection if they will continue the drive home, instead of stopping for a midday meal. Factors such as an exhausted camper, a crying infant, or an illness may prevent the planned stop and expenditure.

The data collection procedure utilized made it impossible to determine a response rate. Participants completed the questionnaire and passed the clipboard to the next willing participant. This process makes it difficult to determine how many individuals decided not to fill out the questionnaire and simply passed the clipboard to the next willing 
individual. Recommendations for ways to eliminate this issue, such as the use of interviewers to collect data, are discussed further in a later section.

This study is limited by the method of data analysis. The initial design for data analysis was to utilize the input-output analysis method IMPLAN (IMpact analysis for PLANing) where the data would be interpreted based on current economic trends and other factors specific to the impact region. After reading several research articles focusing on the IMPLAN model, having numerous email conversations with many of the IMPLAN specialists working within the state of California, and discussing the analysis model with a Cal Poly professor trained in the use of the package, it was determined that the IMPLAN analysis model would not be used. The impact region surveyed, Newaygo County, is very small for the IMPLAN analysis method. The expenditure categories on the questionnaire with the most reported impact, "auto expenses" and "food and beverage" expenditures, are the two areas with the smallest impact within the IMPLAN model. The expenditure category with the highest impact in most economic impact studies utilizing IMPLAN, "lodging expenses", was the category of least expenditure in this study. Lastly, it was advised that the data collected could have been run through the IMPLAN software, but the results from that analysis would have been similar to those found through a program such as Minitab and Microsoft Excel since county level multipliers and secondary effects could not be determined. Therefore, it was determined that Minitab and Microsoft Excel would be effective and appropriate tools for this data analysis.

This study is limited by the exclusion of data from local businesses. Information regarding job creation within the county was not collected or calculated. Camp Henry 
employee salaries were not included as part of the data and expenditures of employees within the county were not included. The expenditures of campers and staff on "holdovers", campers staying more than one consecutive week and staying on-site for the weekend, were not included. The total economic impact is the sum of the direct and all secondary economic benefits (Stynes, 2005) and because the IMPLAN analysis method was not used and direct and secondary economic benefits could not be calculated, the total economic impact of Camp Henry on Newaygo County, Michigan could not be determined.

\section{Recommendations for Future Studies}

The following sections address the issues which arose during this study. Included here are recommendations for the instrument, data collection, data analysis, and recommendations for future research.

\section{$\underline{\text { Recommendations for the instrument }}$}

There are a few ways in which the questionnaire could be altered, should a similar study be conducted. Most of these recommended changes came to the attention of the researcher while analyzing the data. The instrument used in this study provided one column for participants to report their in-county expenditures. If two columns had been given, one with the amount spent in-county and one with the amount spent outside of the county, reporting accuracy may have been improved and the data from out of county expenditures could be compared to in-county expenditures.

In future studies, it would be possible to divide expenditure categories into smaller, more specific listings and pull them together upon data analysis. For example; instead of listing "auto expenses" with an open ended line to fill in the amount, separate 
lines for "gasoline", "auto repair", and "preventative maintenance" could be given and pulled together later as "auto expenses" when analyzing the data. A category for “entertainment expenses" would be included and when asking respondents to report, we would ask for "books, magazines, newspaper purchases", "movie ticket purchases", and "recreational equipment rentals" and, like above, pull those together into one category for data analysis. By doing this, the researcher may be able to collect more specific and reliable data.

A few questions were not included on the questionnaire that would be beneficial to the purpose of the study. Data including the number of campers traveling in each party and ages of those campers would be beneficial to collect. When attempting to analyze the data, the researcher had the reported number of individuals traveling in each group, but did not collect data indicating whether those individuals were campers, non-camping children, infants, or other adults traveling with the respondent. Understanding the group compositions would be beneficial for further analysis and potential comparisons.

\section{$\underline{\text { Recommendations for data collection }}$}

The pilot study did not include the population of interest, Camp Henry patrons. In the future, it would be beneficial to include a small test group of the population of interest to verify that the instrument is appropriate. The purposive random cluster sampling method led to data first being collected on arrival day of week three of the eight week summer camp session. Individuals from weeks one and two would have been appropriate pilot study subjects. The method of data collection was effective in attaining the information desired, but mail-in or email questionnaires would be potential methods to use to obtain a larger sample size. Questionnaires would be emailed or post-mailed to the 
address of each registered camper and a response rate could be determined. The way in which data were collected for this study made it impossible to retroactively determine a response rate. An email or mail-in questionnaire may be beneficial in the future because participants would not be asked to predict their expenditures and would be able to report the actual, and not predicted, amount spent while returning campers to their residence upon completion of the residential camp experience. Downfalls of utilizing an email questionnaire would be that it excludes "potentially important segments of the population of small towns and rural communities" (Smyth, Dillman, Christian, \& O’Neill, 2010, 1423). Many older individuals and persons living in rural communities have what is termed "low coverage", meaning that they do not have internet access readily available (Smyth, et al., 2010). Another downfall of using an email questionnaire would be that many individuals do not respond to emails they don't recognize. "Emails have become an ephemeral form of communication that can easily be ignored, discarded, or forgotten" (Millar \& Dillman, 2011, p.256). Individuals may not open the email for concern of downloading a computer virus. “... (I)t may be more difficult to establish legitimacy of the surveyor through emails, which are often regarded as 'spam' and viewed with some degree of suspicion" (Millar \& Dillman, 2011, p.256). Downfalls of utilizing a mail-in questionnaire would be that it would be costly to the researcher and participants delaying response after returning home may not accurately recall their expenditures.

One way to avoid the downfalls of the aforementioned data collection methods would be to have interviewers on site to collect the desired data from participants. This would eliminate the issue of individuals not participating in the study due to factors such as tending to small children or carrying infants. An interviewer, or interviewers, would 
most likely increase the response rate and allow for a larger sample size. This would be done prior to camper registration or upon completing registration. Another option would be for participants to attend a mandatory parent meeting, in which they would be asked to complete a written questionnaire or would be interviewed for responses. In either case, these alterations to the data collection procedure would increase the sample size. However, that sample has the potential to be biased since many parents or guardians who have brought children to Camp Henry in previous summers or weeks of that summer would likely disregard the mandatory parent meeting, unless an incentive was offered. In regards to online surveys, incentives of various types where found to increase web response rates by an average of 2.8 percent (Gortiz, 2006). If incentives were used for Camp Henry patrons, they could include resident or family camp session discounts, small amounts of cash, or a Camp Henry t-shirt. Incentives would only be a viable option if the residential camp or the researching party had funding to do so, which was not the case at the time of data collection.

\section{$\underline{\text { Recommendations for data analysis }}$}

IMPLAN (IMpact analysis for PLANing) is one of the most frequently used methods of data analysis for economic impact studies. It would be beneficial to use the IMPLAN model and determine county level multipliers, employment multipliers, economic returns to residents, number of professional positions created or sustained because of the presence of the residential camp and other economic forecasting estimates. IMPLAN would make it possible to extrapolate from the data collected. The small sample size does not allow for extrapolation from the data, which impedes this study a 
great deal. Future studies utilizing the IMPLAN model would be able to give a superior indication of the economic effects a residential camp has on its host community.

\section{$\underline{\text { Recommendations for future research }}$}

Economic impact studies conducted on similar sites and actions, which meet all the criteria to be defined as such, should be conducted in order to build the research base and fill the gap that currently exists in regards to the economic impact of residential camps to their host communities. No matter the outcome of future economic impact analyses, it is best to have a modest figure that is an honest representation than a wild claim that is not justified, as described in the review of the literature.

For prospective studies, a comparison of residential camps in different impact regions would be worthwhile and noteworthy to the professional camp community. Site differences which could be evaluated include proximity to local businesses, rural versus urban settings, or population characteristics. Comparing a number of residential camps in similar settings with similar clientele to determine if the economic impacts would vary significantly would be an interesting evaluation for the camp industry. Comparisons of the economic impacts or types of expenditures made by individuals attending different categories of camps such as family, sports, church, music, art, or science, could be made. This would assist businesses in finding their target audience and in aiming their marketing strategy to profit from the expenditures each camp-going population.

It would be extremely favorable to use this questionnaire or a similar one with another residential camp and use the IMPLAN model for data analysis. Obtaining a larger sample size through mail-in or email questionnaires to all registered campers' parents or via on-site interviewers would be beneficial. A longitudinal study, where individuals are 
interviewed in person on arrival day and over the phone or via email upon returning home, would capture both the arrival trip expenditures and the departure trip expenditures. A purposive random cluster sample method could still be utilized by choosing a specific week or weeks to sample or, if funding allows, a mail-in questionnaire could be sent to a parent or guardian of every registered camper for an entire summer.

\section{Limitations}

This study is limited because the pilot study did not include individuals similar to the sample collected. It was reviewed by members of the American Camp Association's Committee for the Advancement of Research and Evaluation and California Polytechnic State University students, not Camp Henry patrons. This study is limited by the size of the sample. Due to the small sample size, relationships that potentially exist cannot be determined. With a larger sample size, it is believed that the P value of 0.077 for the returning camper groups spending more than the first time camper groups could be determined at a statistically significant level. The data may be incomplete due to the willingness of the individuals to fill out the questionnaire, the time available to complete the forms, and may be biased by the memory of the participants. The study is limited due to the participants' inability to accurately predict the future; they cannot predict that their car will break down and need a tow truck and repairs or that they will not eat lunch on the drive home, as originally planned.

This study is limited by the small size and rural setting of Newaygo County and by the fact that most of Camp Henry's patrons come to the site from not very far outside the impact region; most reported being from Grand Rapids, which is 35 miles south of 
Camp Henry. Events where no overnight stay is required will generate a very small economic impact since lodging may be one of the largest expenditure categories (Crompton \& Lee, 2000). In order to determine a true economic impact, patrons would need to travel to the facility from outside of Newaygo County, the defined impact region.

\section{Summary}

Although there were no statistically significant findings from the data, there is value inherent in measuring the expenditures of resident summer camp patrons. With over 2,400 camps operating nationwide (American Camp Association, 2012) the possibility of exploring the camp going population and their monetary value to host communities is a worthwhile subject for further scrutiny. The information presented here can be used as a starting point for future studies on expenditures of resident camp patrons. 


\section{REFERENCES}

American Camp Association (2012). Retrieved January 12, 2012, from http://www.acacamps.org/about/profile.php

Camp Henry (2006). Retrieved March 5, 2006, from www.camphenry.org

Cordell, K., Bergstrom, J., \& Watson, A. (1992). Economic growth and interdependence effects of state park visitation in local and state economies. Journal of Leisure Research, 24, 253-268.

Crompton, J. L. (1995). Economic impact analysis of sports facilities and events: eleven sources of misapplication. Journal of Sport Management. 9, 14-35.

Crompton, J.L. (2001). The impacts of parks on property values: A review of the empirical evidence. Journal of Leisure Research. 33(1), 1-31.

Crompton, J.L. (2004). Beyond economic impact: An alternative rationale for the public subsidy of major league sports facilities. Journal of Sport Management. 18, 4058.

Crompton, J.L. \& Kaczynski, A.T. (2004). Trends in state governments' expenditures on parks and recreation 1989/90 through 1999/2000. Journal of Park and Recreation Administration. 22(2), 102-117.

Crompton, J.L. \& Lee, S. (2000). Programs that work; The economic impact of 30 sports tournaments, festivals, and spectator events in seven U.S. cities. Journal of Park and Recreation Management, 18(2), 107-126.

Crompton, J.L., Lee, S. \& Shuster, T. (2001). A guide for undertaking economic impact studies: the Springfest example. Journal of Travel Research. 40 Aug, 79-87.

Dawson, S.A., Blahna, D.J., \& Keith, J.E. (1993). Expected and actual regional economic impacts of Great Basin National Park. Journal of Park and Recreation Administration. 11(4), 45-59.

Dean, G., Getz, M., Nelson, L., \& Siegfried, J. (1978). The local impact of state parks. Journal of Leisure Research, 10, 98-112.

Donnelly, M.P., Vaske, J.J., DeRuiter, D.S., \& Loomis, J.B. (1998). Economic impacts of state parks: effect of park visitation, park facilities, and county economic diversification. Journal of Park and Recreation Administration, 16(4), 57-72.

Factfinder. (2012). Retrieved February $11^{\text {th }}, 2012$ from http://factfinder2.census.gov/face s/tableservices/jsf/pages/productview.xhtml?pid=DEC_10_DP_DPDP1\&prodTyp $\mathrm{e}=$ table 
Glisson, P., \& Arbes, T. (1996). Economic impact on the State of Georgia of hosting the 1996 Olympic Games. Government Finance Review, June, 19-21.

Goritz, A. S. (2006). Incentives in web studies: methodological issues and a review. International Journal of Internet Science, 1, 58-70.

Henderson, K.A. and Bialeschki, D.M. (2002). Evaluating leisure services; making enlightened decisions ( ${ }^{\text {nd }}$ Ed.). Venture Publishing, Inc. State College, Pennsylvania.

Hendricks, W., Love, T., \&Hamilton, L. (2002). Economic Impact of Morro Bay State Park Visitors. Report prepared for the California Department of Parks and Recreation.

Johnson, R.L., Obermiller, F., \& Radtke, H. (1989). The economic impact of tourism sales. Journal of Leisure Research, 21, 140-154.

Kanters, M.A., Carter, D., \& Pearson, B. (2001). A community-based model for assessing the economic impact for sport and recreation services. Journal of Park and Recreation Administration. 19(2), 43-61.

Lee, H. C. (2003). Estimating recreational boater expenditures on trips and boating use in a wave survey. Leisure Sciences, 25, 381-397.

Loomis, J.B. (1989). Estimating the economic activity and value from public parks and outdoor recreation areas in california. Journal of Park and Recreation Administration, 7(2), 56-65.

Loomis, J.B. \& Walsh, R.G. (1997). Recreation economic decisions. State College, PA: Venture Publishing, Inc.

Mapquest (2012). Retrieved February $11^{\text {th }}, 2012$ from www.mapquest.com.

Millar, M. M. \& Dillman, D.A. (2011). Improving response to web and mixed-mode surveys. Public Opinion Quarterly, 75(2), 249-269.

Mitra, A. \& Lankford, S. (1999). Research methods in park, recreation, and leisure services. Champaign, Il: Sagamore.

Newaygo County Government website (2006). Retrieved April 24, 2006, from http://www.countyofnewaygo.com/

Orams, M.B. (2002). Humpback whales in Tonga: An economic resource for tourism. Coastal Management, 30, 361-380. 
Smyth, J. D., Dillman, D. A., Christian, L. M., \& O’Neill, A. C. (2010). Using the internet to survey small towns and communities: limitations and possibilities in the early $21^{\text {st }}$ century. American Behavioral Scientist, 53 (9), 1423-1448.

Stynes, D.J. (2005). Economic significance of recreational uses of national parks and other public lands. Social Science Research Review, 5, 1. Retrieved May 23, 2006, from http://www.nature.nps.gov/socialscience/docs/SSRR 7.pdf 


\section{APPENDIX}

A. Camp Henry Participant Questionnaire 


\section{Camp Hensy Susvey}

Please respond to the questions on the following pages as completely as possible. Each section on the questionnaire relates to your experiences while traveling to and from Camp Henry in

Newaygo County, please see map below. $\sim$ Thank you.

\section{Newaygo County includes the towns of Newaygo, Fremont, Grant, White Cloud, Hesperia, Brohmna, and Bitely.}

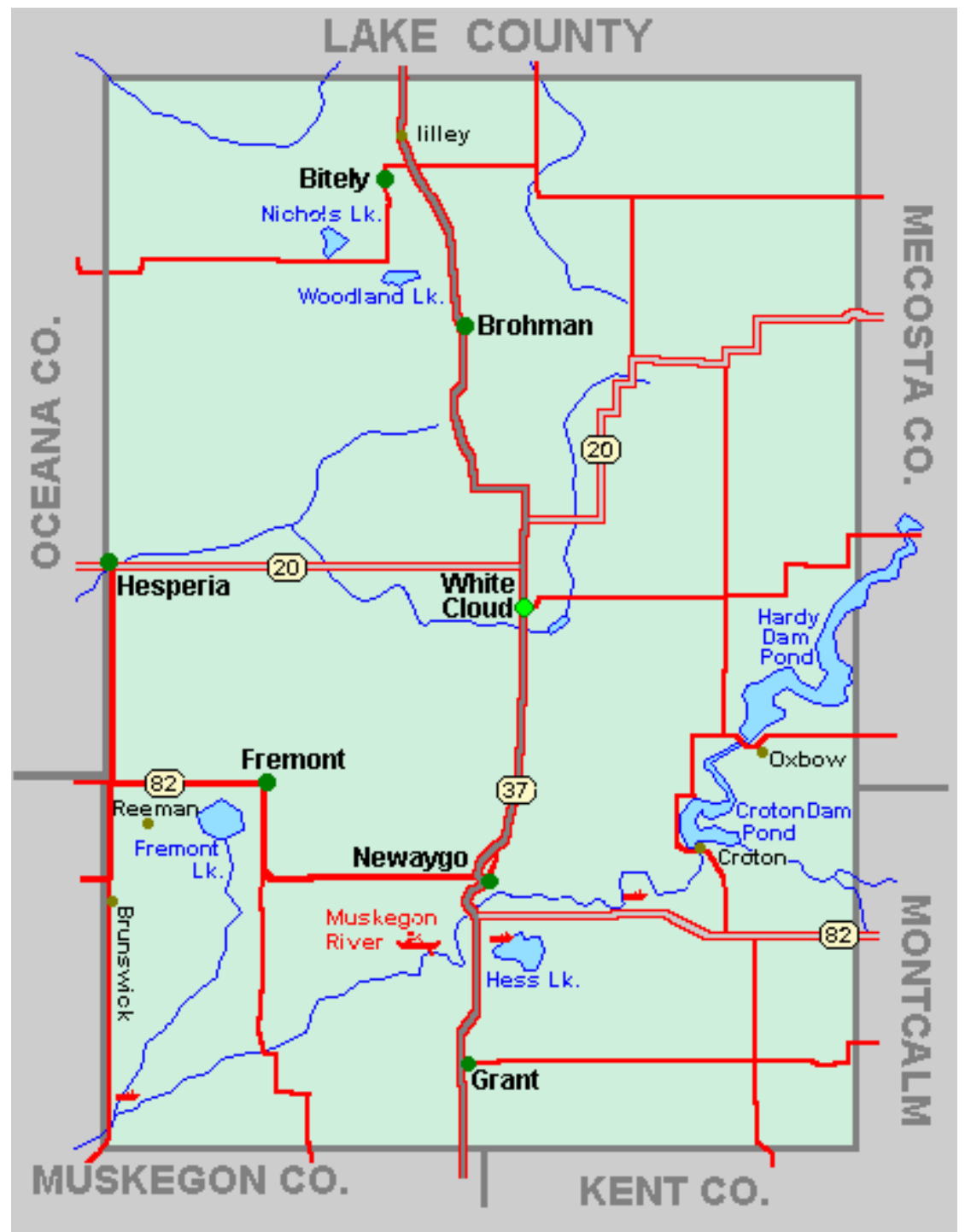

To better understand the economic impact of visitors to Camp Henry on the surrounding communities we are interested in finding out the approximate amount of money you and other visitors in your immediate group spent in Newaygo County during your visit to Camp Henry. Your immediate group includes you and all other passengers in your car. We understand that these questions may be difficult to answer, but please do your best because your responses are very important to our efforts and will help document the economic impact that Camp Henry has on Newaygo County. 


\section{Informed Consent Form for Cal Poly Research}

Informed consent to participate in the Economic Impact Study of Camp Henry.

A research project on the economic impact of Camp Henry is being conducted by Amy Fitzpatrick and Dr. Jeff Jacobs in the Department of Agriculture at Cal Poly, San Luis Obispo. The purpose of the study is to determine the economic impact of Camp Henry on the surrounding towns within the county of Newaygo.

You are being asked to take part in this study by completing a self-administered questionnaire. Your participation will take approximately five minutes. Please be aware that you are not required to participate in this research and may omit any questions you prefer not to answer. You may discontinue your participation at any time without penalty.

There are no possible risks associated with participation in this study.

Your confidentiality will be protected by the anonymity of the questionnaire. Please do not write your name on any part of the questionnaire. Your responses will be provided anonymously to protect your privacy. Potential benefits associated with the study include finding the monetary value that Camp Henry provides in the county of Newaygo, Michigan.

If you have questions regarding this study or would like to be informed of the results when the study is completed, please feel free to contact Amy Fitzpatrick and/or Dr. Jeff Jacobs at (805) 756-7628. If you have questions or concerns regarding the manner in which the study is conducted, you may contact Steve Davis, Chair of the Cal Poly Human Subjects Committee, at 756-2754, or Susan Opava, Dean of Research and Graduate Programs, at 756-1508.

If you agree to voluntarily participate in this research project as described, please indicate your agreement by completing the attached questionnaire. Your responses will be provided anonymously to protect your privacy. Thank you for your participation in this research. 


\section{CAMPER DROP OFF}

Please consider the approximate amount your entire group spent in each of the following categories while traveling through Newaygo County to drop your camper off at Camp Henry as well as the amount you anticipate spending in Newaygo Country after leaving Camp Henry today.

\section{Type of expenditure}

A. Lodging expenses (hotels/motels, bed and breakfast, private campgrounds)

B. Food and Beverages (restaurants, concessions, bars, cafes, etc.)

C. Private auto expenses (gas, oil, repairs, parking fees, public transportation)

D. Retail shopping (souvenirs, gifts, film, camp supplies, groceries, etc.)

E. Recreation activities (equipment purchases/rentals, tours, admission fees, cover charges, services, etc.)

F. Any other expenses

Please specify

Please specify

\section{Amount Spent} In Newaygo County

$\$$

$\$$

$\$$

$\$$

$\$$

$\$$

$\$$

\section{CAMPER PICK UP}

When you return to Camp Henry to pick-up your camper, what is the approximate amount you anticipate your entire group will spend in Newaygo County in each of the following categories? (If someone else will be picking up your camper, please select option G below)

\section{Type of expenditure}

A. Lodging expenses (hotels/motels, bed and breakfast, private campgrounds)

B. Food and Beverages (restaurants, concessions, bars, cafes, etc.)

C. Private auto expenses (gas, oil, repairs, parking fees, public transportation)

D. Retail shopping (souvenirs, gifts, film, camp supplies, groceries, etc.)

E. Recreation activities (equipment purchases/rentals, tours, admission fees, cover charges, services, etc.)

F. Any other expenses

Please specify

Please specify

G. Someone else will be picking up my camper

\section{Anticipated Amount Your Group} Will Spend In Newaygo County

$\$$

$\$$

$\$$

$\$$

$\$$

$\$$

$\$$

$€$ 
This last set of questions provides us with information about you and your group when you visited Camp Henry.
4) Your Gender?
$€ \quad$ Male
$€ \quad$ Female
5) Your Marital Status?
$€ \quad$ Married
$€ \quad$ Unmarried

6) Your Age?

7) Number of people traveling in your immediate party (including yourself)? people

8) Your hometown?

9) Zip Code?

10) Which of the following categories best represents your family's annual income? (check one only)

$\square$ Less than $\$ 10,000$
$\square \$ 10,000$ to $\$ 19,999$
$\square \$ 20,000$ to $\$ 29,999$
$\square \$ 30,000$ to $\$ 39,999$
$\square \$ 40,000$ to $\$ 49,999$
$\square \$ 50,000$ to $\$ 59,999$
$\square \$ 60,000$ to $\$ 69,999$

$\square \$ 70,000$ to $\$ 79,999$
$\square \$ 80,000$ to $\$ 89,999$
$\square \$ 90,000$ to $\$ 99,999$
$\square \$ 100,000$ to $\$ 109,999$
$\square \$ 110,000$ to $\$ 119,999$
$\square \$ 120,000$ to $\$ 129,999$
$\square \$ 130,000$ to $\$ 139,999$

$\square 140,000$ to $\$ 149,999$

$\square \$ 150,000$ to $\$ 159,999$

$\square \$ 160,000$ to $\$ 169,999$

$\square \$ 170,000$ to $\$ 179,999$

$\square \$ 180,000$ to $\$ 189,999$

$\square \$ 190,000$ to $\$ 199,999$

$\square \$ 200,000$ or greater

11) Is this the first summer your children have been campers at Camp Henry?

$$
€ \quad \text { Yes } \quad € \quad \text { No }
$$

\section{Thank you for your time and participation!}

Please fold your completed questionnaire and place in the envelope attached to the back of your clipboard.

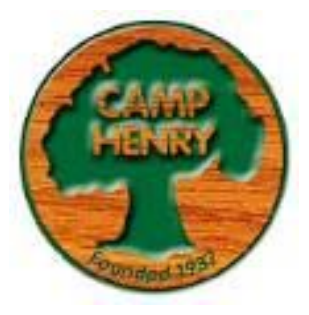

